\title{
EXCEÇÕES SUBSTANCIAIS E (DE)LIMITAÇÃO DOS PODERES DO JUIZ NO PROCESSO CIVIL ${ }^{1}$
}

\section{SUBSTANTIAL EXCEPTIONS AND (DE)LIMITATIONS OF THE POWERS OF THE JUDGES ON CIVIL PROCEDURAL LAW}

Igor Raatz

Pós-doutor, doutor e mestre em Direito pela Universidade do Vale do Rio dos Sinos - UNISINOS. Especialista em processo civil pela Academia Brasileira de Direito Processual Civil ABDPC. Membro do DASEIN - Núcleo de Estudos Hermenêuticos. Membro da ABDpro. Membro do IIDP. Professor do curso de graduação em Direito da Universidade FEEVALE - Novo Hamburgo (RS). Professor em cursos de pós-graduação e graduação. Advogado. igor@raatzanchieta.com.br.

RESUMO: O presente ensaio visa a desvelar o papel exercido pelas exceções substanciais na delimitação dos poderes do juiz no processo civil, notadamente no que diz respeito a atuação ex officio do órgão julgador. Desse modo, partindo do método de abordagem fenomenológico e de uma visão garantista do processo civil, será realizada uma breve apresentação da questão concernente ao conteúdo do objeto litigioso e do seu papel (de)limitador dos poderes do juiz, tendo como hipótese de trabalho a inserção das exceções substanciais dentre o conteúdo do objeto litigioso, ao lado do pedido e da causa de pedir. Os resultados da pesquisa gravitam na premissa de que, por meio das exceções substanciais, o réu amplia o objeto litigioso, o qual se forma, no processo civil, de maneira dinâmica, concluindo-se, com isso, que as exceções substanciais atuam no sentido de limitar a atuação de ofício do órgão jurisdicional no direito processual civil.

\footnotetext{
${ }^{1}$ Artigo recebido em 10/07/2017 e aprovado em 30/07/2017.
} 
PALAVRAS-CHAVE: Exceções substanciais. Garantismo processual. Poderes de juiz. Objeto litigioso.

ABSTRACT: This essay aims to unveil the role of the substantial exceptions on delimiting the powers of the judges on civil procedural law, especially regarding the ex officio judicial activity. This way, under a phenomenological method and based on a vision of guarantee of rights on procedural law, the article offers a brief explanation of the question concerning the content of the object under litigation and its role of (de)limiting the powers of the judges. The work hypothesis is the addition of the substantial exceptions among the content of the object under litigation, along with the claim itself and the cause of action. The results lie on the premise that, by the substantial exceptions, the defendant extends the object under litigation - which is formed dynamically on civil procedure. The conclusion points towards the idea that the substantial exceptions act in a way of limiting the ex officio judicial activity on civil procedural law.

KEYWORDS: Substantial exceptions. Guarantee of rights on procedural law. Powers of the judges. Object under litigation.

SUMÁRIO: Considerações iniciais; 1 Objeto do processo: conteúdo, precisões terminológicas e seu papel (de)limitador dos poderes do juiz no processo civil; 2 Definição conceitual das exceções substanciais; 3 Exceções substanciais como limitadoras da atuação de ofício do juiz; 4 Exceções substanciais como contradireitos do réu; 5 Exceções substanciais, ampliação e formação dinâmica do objeto do processo; Considerações finais; Referências bibliográficas.

\section{Considerações iniciais}

A questão pertinente à (de)limitação dos poderes do juiz é uma das temáticas mais árduas do direito processual civil, e pode ser surpreendida por diferentes perspectivas. Nenhuma delas, porém, é suficiente para, de modo isolado, oferecer uma resposta capaz de lidar com toda a complexidade relacionada à matéria. Um dos possíveis enfoques que, nesse sentido, pode ser mencionado é do estudo do processo civil à luz das diferentes concepções 
de Estado, ótica a partir da qual se faz possível desvelar diferentes formas de distribuição dos poderes das partes e do juiz desde uma leitura histórica e que leva em conta as relações entre sociedade, Estado e indivíduos ${ }^{2}$. Outra forma de abordagem bastante profícua para o trato da questão - e que será o mote deste ensaio - reside no estudo do objeto do processo (que também costuma ser designado por objeto litigioso ou mérito da causa), campo temático no qual se inserem diversos institutos processuais tendentes a delimitar os poderes de atuação do órgão jurisdicional, como é o caso do pedido, da causa de pedir e também das exceções substanciais, cujo estudo costuma ser sonegado quando do tratamento da matéria.

Diante desse quadro, o presente ensaio visa a estudar as exceções substanciais, encarando-as como um dos componentes do objeto litigioso e, portanto, com a função de servir de elemento balizador da atuação de ofício do órgão julgador no processo civil. Sob essa perspectiva, será defendida a tese de que a delimitação do objeto litigioso não cabe somente à parte autora, mas também ao réu, notadamente quando este oferece alguma espécie de exceção substancial, o que permite superar a visão meramente estática do objeto litigioso. Para tanto, será realizada (i) uma breve apresentação da questão concernente ao conteúdo do objeto litigioso e ao seu aspecto (de)limitador dos poderes do juiz, passandose, na sequência, (ii) ao estudo conceitual das exceções substanciais a partir de sua construção histórica, (iii) à abordagem das exceções substanciais como contradireitos do réu, (iv) ao exame das teses da ampliação do objeto litigioso pelo réu e (v) da formação progressiva do objeto litigioso, a fim de, ao final, desvelar que também as exceções substanciais atuam no sentido de limitar a atuação de ofício do órgão jurisdicional no processo civil.

1 Objeto do processo: conteúdo, precisões terminológicas e seu papel (de)limitador dos poderes do juiz no processo civil

Para uma adequada compreensão dos limites de atuação de ofício do juiz no processo civil, é imprescindível deixar claro o que se entende por objeto do processo (objeto litigioso ou mérito da causa), bem como qual o seu conteúdo. Trata-se de tema tortuoso e pouco

\footnotetext{
${ }^{2}$ Para uma análise mais profunda do tema, ver RAATZ, Igor. Autonomia privada e processo civil: negócios jurídicos processuais, flexibilização procedimental e o direito à participação na construção do caso concreto. Salvador: Juspodivm, 2016.
} 
Revista Eletrônica de Direito Processual - REDP.

Rio de Janeiro. Ano 11. Volume 18. Número 2. Maio a Agosto de 2017

Periódico Quadrimestral da Pós-Graduação Stricto Sensu em Direito Processual da UERJ

Patrono: José Carlos Barbosa Moreira. ISSN 1982-7636. pp. 297-326

www.redp.uerj.br

enfrentado pela doutrina processual. Seu estudo, no entanto, é crucial, inclusive para que sejam evitadas confusões conceituais.

Não há dúvida alguma de que a atuação do órgão jurisdicional está condicionada e, também, limitada pela demanda ( $\operatorname{art.} 2^{\circ}$., CPC). Todavia, não há, em sede doutrinária, grande precisão acerca do conteúdo da demanda, especialmente se as alegações sobre os fatos estariam abarcadas pelo seu conteúdo. Pode-se dizer, com isso, que, embora não exista controvérsia a respeito da autonomia conferida ao autor no sentido de autodeterminar se irá a juízo exigir do Estado a prestação da tutela jurisdicional ou não, são bastante nebulosos os limites que lhe cabe impor à atuação jurisdicional desencadeada pela demanda.

Na verdade, a demanda consiste no "mero acto de iniciación procesal" qual se mostra equivocado equipará-la ou confundi-la com a pretensão processual ${ }^{4}$ - a qual nada mais é que a faceta do objeto litigioso na perspectiva do autor - o que acabou por obscurecer quais seriam os limites fixados pelo autor relativamente à atuação do juiz no processo. Afinal, a resposta para esse problema não pode ser encontrada na demanda - que é, repita-se, essencialmente ato de iniciação do processo - mas no próprio objeto do processo, o qual tão somente tem o germe da sua definição na demanda ${ }^{5}$, com ela, porém, não se confundindo ${ }^{6}$.

\footnotetext{
${ }^{3}$ GUASP. Jaime. La pretensión procesal. $2^{\mathrm{a}}$ ed. Prólogo de Manuel Alonso Olea. Madrid: Editorial Civitas, S.A., 1985, p. 57.

${ }^{4}$ Confusão conceitual, que, segundo Schwab, é muito mais comum na Itália que na Alemanha: "la ragione per cui il problema del quale ci occupiamo non ha mais raggiunto in Italia l'importanza che riveste in Germania sta, a nostro avviso, nel fatto che in Italia non si distingue $1^{\prime}$ Anspruch dalla Klage così rigidamente come in Germania" (SCHWAB, Karl Heinz. La teoria dell'oggetto del processo nell'attuale dottrina tedesca. Studi in onore di Antonio Segni. v. IV. Milano: Casa editrice dott. a. giuffrè, 1967, p. 313). No Brasil, são raros os autores que se apereceberam dessa distinção, podendo destacar, dentre eles, Dinamarco (DINAMARCO, Cândio Rangel. O conceito de mérito em processo civil. Revista de processo. v. 34. São Paulo: Revista dos Tribunais, 1984, p. 29).

${ }^{5}$ Registre-se, desde já, que o caráter dinâmico do processo impõe uma concepção dinâmica do objeto do processo, o qual, embora tenha o seu germe na demanda, não é fixado de modo estático, o que se deve ao caráter hermenêutico do fenômeno jurídico. A fixação do objeto do processo vai se dar conforme o caso concreto a partir do esforço conjunto de atividades dos agentes do processo (juiz e partes) e tem seu limite nos marcos preclusivos da fase preparatória da causa.

${ }^{6}$ Conforme Guasp, "concedido por el Estado el poder de acudir a los Tribunales de Justicia para formular pretensiones (derecho de acción), el particular puede reclamar cualquier bien de la vida frente a otro sujeito distinto, de un órgano estatal (pretensión procesal) iniciando para ello el correspondiente proceso (demanda), ya sea al mismo tempo, ya sea después de esta iniciación" (GUASP. Jaime. La pretensión procesal. $2^{\mathrm{a}}$ ed. Prólogo de Manuel Alonso Olea. Madrid: Editorial Civitas, S.A., 1985, p. 57).
} 
Revista Eletrônica de Direito Processual - REDP.

Rio de Janeiro. Ano 11. Volume 18. Número 2. Maio a Agosto de 2017

Periódico Quadrimestral da Pós-Graduação Stricto Sensu em Direito Processual da UERJ

Patrono: José Carlos Barbosa Moreira. ISSN 1982-7636. pp. 297-326

www.redp.uerj.br

Autorizados setores da doutrina processual são uníssonos em afirmar que o autor fixa, na demanda, o objeto do processo $^{7}$. Apesar de não se adotar integralmente essa posição, pois como será melhor abordado posteriormente, o objeto do processo forma-se progressivamente, não há dúvida que os elementos mínimos e basilares do objeto do processo, na grande maioria dos casos, são fixados pelo autor na demanda e que eles são decisivos para delimitação dos poderes das partes e do juiz no processo. Essa constatação é suficiente para que se possa inverter o foco da análise da limitação dos poderes do juiz, deixando de lado a atenção até então empregada na demanda, para voltar os olhos para o objeto do processo ${ }^{8}$.

Antes de avançar no tema, cabe precisar o que se quer expressar com o termo "objeto do processo". A primeira grande advertência é no sentido que "a finalidade, o escopo do processo, não devem ser relacionados à ideia de objeto do processo, que é ambígua e, por isso mesmo, pode levar a confusões" ${ }^{9}$. Deve-se, portanto, entender por objeto do processo

\footnotetext{
${ }^{7}$ A propósito, Dinamarco afirma que "é a demanda que define o objeto do processo, ou 'objeto litigioso do processo', em torno do qual será exercida a jurisdição em cada caso concreto, ao juiz não sendo lícito desconsiderá-lo, ampliá-lo por iniciativa própria ou pronunciar-se acerca de outro objeto" (DINAMARCO, Cândio Rangel. O conceito de mérito em processo civil. Revista de processo. v. 34. São Paulo: Revista dos Tribunais, 1984, p. 23). Do mesmo modo, Giancarlo Giannozzi refere ser verdadeiro "che è l'atore a fissare con la proposizione della sua domanda l'oggetto del processo" (GIANNOZZI, Giancarlo. La modificazione della domanda nel processo civile. Milano: Dott. A. Giuffrè, 1958, p. 16). Igualmente, De Stefano afirma que "se ci domandiamo quale è il fatto giuridicio che pone l'oggetto del processo, non vi è da rispondere se non che il fatto assolutamente iniziale del processo stesso è la domanda. Onde è naturale pensare che appunto la domanda sia il fatto attraverso il quale appare quell'oggetto. Questo, dunque, viene posto dalla domanda, o meglio, viene determinato in funzione dell'oggetto della domanda" (DE STEFANO, Giuseppe. Per una teoria dell'oggetto del processo. Scritti giuridici in memoria di Piero Calamandrei. Volume Terzo. Padova: Casa Editrice Dott. Antonio Milani, 1958, p. 239). Na mesma linha, ver PICÓ I JUNOY, Joan. La modificación de la demanda en el processo civil: reflexiones sobre la prohibición de mutatio libelli. Valencia: Tirant lo blanch, 2006, p. 15.

${ }^{8}$ Nessa perspectiva entende De Stefano que "l'oggetto del processo determina dei poteri e doveri di parte e di giudice, e, se non è un fatto giuridico, deve almeno essere posto da un fatto giuridicio" (DE STEFANO, Giuseppe. Per una teoria dell'oggetto del processo. Scritti giuridici in memoria di Piero Calamandrei. Volume Terzo. Padova: Casa Editrice Dott. Antonio Milani, 1958, p. 239).

${ }^{9}$ SANCHES, Sydnei. Objeto do processo e objeto litigioso do processo. AJURIS. n. 16. Porto Alegre: AJURIS, 1979, p. 139. No mesmo sentido, CORRÊA, Fábio Peixinho Gomes. O objeto litigioso no processo civil. São Paulo: Quartier Latin, 2009, p. 27. SANTOS, Andrés de La Oliva. GIMÉNEZ, Ignacio Díez-Picazo. Derecho procesal civil: el proceso de declaración. Conforme a la ley 1/2000, de 7 de enero de enjuciamiento civil. Madrid: Editorial centro de estudios ramón areces S.A, 2000, p. 41.
} 
Revista Eletrônica de Direito Processual - REDP.

Rio de Janeiro. Ano 11. Volume 18. Número 2. Maio a Agosto de 2017

Periódico Quadrimestral da Pós-Graduação Stricto Sensu em Direito Processual da UERJ

Patrono: José Carlos Barbosa Moreira. ISSN 1982-7636. pp. 297-326

www.redp.uerj.br

"aquello sobre lo que se proyecta la actividad procesal (del órgano jurisdiccional y de las partes) en cada proceso" ${ }^{10}$. Trata-se da causa eficiente do processo, e não da sua causa final ${ }^{11}$. Com efeito, quando se fala em objeto do processo se está falando do próprio conteúdo do processo, daquilo que é posto diante do juiz e sobre o qual giram todas as atividades desenvolvidas no processo $^{12}$. Um processo sem objeto careceria de conteúdo e, consequentemente, operaria no vazio ${ }^{13}$. Desse modo, torna-se imprescindível investigar o conteúdo do processo, o material debatido em juízo e submetido à apreciação e julgamento ${ }^{14}$.

O tema da definição do objeto do processo, no entanto, é extremamente difícil ${ }^{15}$. Independente das diversas teorias acerca do tema, pode-se, numa primeira aproximação conceitual, referir que "o objeto do processo é, em outras palavras, o mérito da causa (meritum causae)"16 e que é sobre ele que se irão centrar as atividades desenvolvidas no processo.

Proporcional à dificuldade que o tema oferece é a sua importância prática. Ele costuma ser considerado como "denominatore unitario" de pelo menos quatro grupos de problemas: modificação da demanda, litispendência, cumulação objetiva de demandas e limites objetivos da coisa julgada ${ }^{17}$. Dentre esses quatro temas, três deles, pelo menos, ligam-

${ }^{10}$ SANTOS, Andrés de La Oliva. GIMÉNEZ, Ignacio Díez-Picazo. Derecho procesal civil: el proceso de declaración. Conforme a la ley $1 / 2000$, de 7 de enero de enjuciamiento civil. Madrid: Editorial centro de estudios ramón areces S.A, 2000, p. 41.

${ }^{11}$ CORRÊA, Fábio Peixinho Gomes. O objeto litigioso no processo civil. São Paulo: Quartier Latin, 2009, p. 27.

12 DINAMARCO, Cândio Rangel. O conceito de mérito em processo civil. Revista de processo. v. 34. São Paulo: Revista dos Tribunais, 1984, pp. 23-34. A doutrina salienta que a palavra 'objeto' significa etimologicamente 'pôr diante de', tanto na origem latina do termo $(o b+i e c t u m)$, quanto na sua versão germânica (gegen + Stand)" (CABRAL, Antônio do Passo. Coisa julgada e preclusões dinâmicas: entre continuidade, mudança e transição de posições processuais estáveis. Salvador: Editora JusPODIVM, 2013, p. 86). No mesmo sentido, SANTOS, Andrés de La Oliva. GIMÉNEZ, Ignacio Díez-Picazo. Derecho procesal civil: el proceso de declaración. Conforme a la ley 1/2000, de 7 de enero de enjuciamiento civil. Madrid: Editorial centro de estudios ramón areces S.A, 2000, pp. 41-42.

${ }^{13}$ ASENJO, Jiménez. Teoría del objeto procesal. Revista de derecho privado. XXXIV, n. 398, 1950, p. 240.

14 CABRAL, Antônio do Passo. Coisa julgada e preclusões dinâmicas: entre continuidade, mudança e transição de posições processuais estáveis. Salvador: Editora JusPODIVM, 2013, p. 46.

${ }^{15}$ Nesse sentido, SCHWAB, Karl Heinz. El objeto litigioso en el proceso civil. Buenos Aires: E.J.E.A., 1968, passim.

${ }^{16}$ DINAMARCO, Cândio Rangel. O conceito de mérito em processo civil. Revista de processo. v. 34. São Paulo: Revista dos Tribunais, 1984, p. 24. Daí que, conforme Dinamarco, “o problema é um só e a busca do objeto do processo outra coisa não é, senão a busca do conceito de mérito" (Idem. Ibidem). No mesmo sentido, ASSIS, Araken de. Cumulação de ações. 4. ed. São Paulo: Rev. dos Tribunais, 2002, p. 106.

${ }^{17}$ DE STEFANO, Giuseppe. Per una teoria dell'oggetto del processo. Scritti giuridici in memoria di Piero Calamandrei. Volume Terzo. Padova: Casa Editrice Dott. Antonio Milani, 1958, p. 233. No mesmo sentido, TARZIA, Giuseppe. Problemi del processo civile di cognizione. Padova: CEDAM - Casa Editrice Dott. Antonio Milani, 1989, p. 108. SCHWAB, Karl Heinz. El objeto litigioso en el proceso civil. Buenos Aires: 
Revista Eletrônica de Direito Processual - REDP.

Rio de Janeiro. Ano 11. Volume 18. Número 2. Maio a Agosto de 2017

Periódico Quadrimestral da Pós-Graduação Stricto Sensu em Direito Processual da UERJ

Patrono: José Carlos Barbosa Moreira. ISSN 1982-7636. pp. 297-326

www.redp.uerj.br

se diretamente à questão de saber o conteúdo sobre o qual desenvolvem-se "i poteri di discussione delle parti e di decisione del giudice, sia nel processo in corso (domanda nuova), sia in altro processo che si svolga nel medesimo tempo (litispendenza), sia infine in un processo futuro (limiti oggettivi del giudicato) ${ }^{18}$.

$\mathrm{Na}$ presente investigação, importa estudar o objeto do processo tendo em vista a relevância que esse instituto tem para (de)limitar o âmbito de atuação das partes e do juiz no processo civil, uma vez que, conforme Manuel Ortells Ramos "son diferentes los poderes que al órgano jurisdiccional y a las partes corresponden respecto al objeto procesal" "19. Essa perspectiva de análise da questão também pode ser encontrada em Domínguez, Sendra e Catena, para os quais o objeto do processo serve, em primeiro lugar, "para fijar al ámbito cognoscitivo de la decisión judicial, creando en el Juez la obligación de ser congruente única y exclusivametne con lo solicitado en la pretensión del actor"20. Trata-se aqui, como já referido no item anterior, de uma mudança no ângulo de visão a respeito dos limites de atuação das partes e do juiz, na medida em que, sendo a demanda um mero ato de iniciação do processo, ela não oferece o substrato material suficiente para que se possa enfrentar tão intrincando problema.

Embora inexista consenso doutrinário acerca do objeto do processo, não se pode negar uma "sempre crescente processualizzazione dell'oggetto",21, ao ponto de se dizer que, na doutrina alemã, "il significato strettamente processuale dello (Streitgegenstand) é punto

E.J.E.A., 1968, em especial a parte II. DOMÍNGUEZ, Valentín Cortés. SENDRA, Vicente Gomeno. CATENA. Víctor Moreno. Derecho Procesal civil. Madrid: Editorial Colex, 1997, pp. 120-121.

${ }^{18}$ DE STEFANO, Giuseppe. Per una teoria dell'oggetto del processo. Scritti giuridici in memoria di Piero Calamandrei. Volume Terzo. Padova: Casa Editrice Dott. Antonio Milani, 1958, p. 233.

${ }^{19}$ RAMOS, Manuel Ortells. Derecho procesal civil. Navarra: Aranzadi Editorial, 2000, p. 249. Assim, as partes têm "el monopolio sobre la configuración y proposición del objeto del processo, mientras que el órgano jurisdiccional está excluido de esa labor y su función respecto al objeto procesal consiste en ejercer su potestad de resolver, de juzgar sobre el mismo" (RAMOS, Manuel Ortells. Derecho procesal civil. Navarra: Aranzadi Editorial, 2000, p. 249). É possível verificar também no pensamento de Schwab, a análise da questão envolvendo "a liberdade de disposição pelas partes tendo em vista o objeto da causa (objeto litigioso)", o que também denota uma mudança de foco no tratamento da questão proposta (SCHWAB, Karl Heinz. Introdução ao direito processual civil alemão. v. 3. Revista de Processo. São Paulo: Revista dos Tribunais, 1976, p. 58).

${ }^{20}$ DOMÍNGUEZ, Valentín Cortés. SENDRA, Vicente Gomeno. CATENA. Víctor Moreno. Derecho Procesal civil. Madrid: Editorial Colex, 1997, p. 120.

${ }^{21}$ DE STEFANO, Giuseppe. L'oggetto del processo in un libro recente di Walter J. Habscheid. Scritti giuridici in memoria di Piero Calamandrei. Volume Terzo. Padova: CEDAM, 1958, p. 328. No mesmo sentido, BERZOSA FRANCOS, Maria Victoria. Demanda, 'causa petendi' y objeto del proceso. Cordoba: El Almendro, 1984, p. 12. 
Revista Eletrônica de Direito Processual - REDP.

Rio de Janeiro. Ano 11. Volume 18. Número 2. Maio a Agosto de 2017

Periódico Quadrimestral da Pós-Graduação Stricto Sensu em Direito Processual da UERJ

Patrono: José Carlos Barbosa Moreira. ISSN 1982-7636. pp. 297-326

wWw.redp.uerj.br

ormai fuori discussione" 22 . A grande controvérsia lançada sobre o objeto do processo diz respeito, especificamente, ao seu conteúdo ou, dito de outro modo, aos seus elementos individualizadores. Com efeito, alguns autores adotam uma visão mais restrita de objeto do processo, para formá-lo unicamente a partir do pedido ${ }^{23}$, ao passo que outros entendem que o objeto do processo é composto pelo pedido e pela causa de pedir ${ }^{24}$. No direito brasileiro,

${ }^{22}$ DE STEFANO, Giuseppe. Per una teoria dell'oggetto del processo. Scritti giuridici in memoria di Piero Calamandrei. Volume Terzo. Padova: Casa Editrice Dott. Antonio Milani, 1958, p. 230. Nesse sentido, Antônio do Passo Cabral refere que, "embora tenha havido, na década de 1970, uma reação das teorias materialistas, hoje prevalecem amplamente as teses que buscam critérios processuais para determinar o Streitgegenstand" (CABRAL, Antônio do Passo. Coisa julgada e preclusões dinâmicas: entre continuidade, mudança e transição de posições processuais estáveis. Salvador: Editora JusPODIVM, 2013, p. 87).

${ }^{23}$ Nesse sentido, pode-se mencionar o pensamento dos seguintes autores, de inegável influência para a doutrina brasileira no tratamento da matéria. Friedrich Lent, principal corifeu da teoria material do objeto do processo - para quem em cada demanda judicial, dentro do pedido de uma determinada decisão está a afirmação no sentido de que ao autor corresponde um direito substancial. Em toda demanda, pois, subsiste a afirmação de um direito por parte do autor. Nela reside o núcleo do objeto do processo, na medida em que a causa se desenvolve propriamente para verificar se esse direito afirmado subsiste ou não (LENT, Friedrich. Contributo alla dottrina dell'oggetto del processo. Rivista JUS. Milano, 1953, p. 434). Leo Rosenberg, o qual, na sexta edição do seu Tratado (1954), veio a aderir integralmente à teoria de Schwab, "escludendo il fatto costitutivo dall'ambito della pretesa processuale, nei confronti della quale esso esplicherebbe una mera funzione di individuazione" (TARZIA, Giuseppe. Problemi del processo civile di cognizione. Padova: CEDAM - Casa Editrice Dott. Antonio Milani, 1989, p. 120). A definição do objeto litigioso, a partir de então, passa a ser a seguinte: "la petición dirigida a obtener la declaración, con fuerza de cosa juzgada, de una consecuencia jurídica, y caracterizada por la solicitud presentada" (ROSENBERG, Leo. Lehrbuch des Deutschen Zivilprozessrechts. $6^{\mathrm{a}}$ ed. \$38, II, apud SCHWAB, Karl Heinz. El objeto litigioso en el proceso civil. Traducción del alemán por Tomas A. Banzhaf. Buenos Aires: E.J.E.A., 1968, p. 39, nota 3). Karl Heinz Schwab formula uma teoria acerca do objeto do processo em que o elemento decisivo para delimitá-lo é a solicitação formulada pelo autor. Ela ocupa "el lugar clave en el litigio". É sobre ela que recai a resolução do tribunal. Desse modo, Schwab diz que "el actor peticiona del tribunal la resolución judicial descrita en su solicitud" e que "el objeto de la petición es entonces la especie de forma de tutela jurídica, o sea el pronunciamiento de una sentencia de prestación [condena], declaración o constitución". Nisso reside o significado do termo pedido para o alcance do objeto litigioso, razão pela qual ele pode ser definido como "la petición de la resolución designada en la solicitude" (SCHWAB, Karl Heinz. El objeto litigioso en el proceso civil. Traducción del alemán por Tomas A. Banzhaf. Buenos Aires: E.J.E.A., 1968, p. 243-251). Para Schwab, os fatos (causa de pedir) constituem elemento estranho à delimitação do objeto do processo, o qual estaria centrado no pedido e, consequentemente, na forma de tutela jurisdicional pensada para a resolução do pedido (condenação, declaração ou constituição). Nesse sentido, ele vai dizer que o estado de coisas, a fundamentação da demanda, não são utilizáveis para uma definição geral do objeto litigioso, devendo, pois, serem excluídos da sua definição (SCHWAB, Karl Heinz. El objeto litigioso en el proceso civil. Traducción del alemán por Tomas A. Banzhaf. Buenos Aires: E.J.E.A., 1968, pp. 250-251)

${ }^{24}$ É o caso de Walter Habscheid, cujo grande diferencia teórico reside em considerar que o objeto do processo é composto por dois elementos: "la pretesa (Rechtsbehauptung) dell'attore, quale appare nelle sue conclusioni e che comprende sia il diritto sostanziale sia quello processuale, e lo stato di fatto (Lebenssachverhalt) sucui si basa tale pretesa" (HABSCHEID, Walter. L'oggetto del proceso nel diritto processuale civile tedesco. Rivista di diritto processuale. XXXV, II serie. Padova: CEDAM, 1980, p. 457). Com isso, tem-se que o fundamento da pretensão é considerado como elemento do objeto do processo, o que faz com que Habscheid se distancie da doutrina segundo a qual os fundamentos somente teriam a limitada função de individualizar, quando necessário, o objeto do processo (STEFANO, Giuseppe de. L'oggetto del processo in un libro recente di Walter J. Habscheid. Scritti giuridici in memoria di Piero Calamandrei. Volume Terzo. Padova: CEDAM, 1958, p. 335). Seguem essa mesma linha, SANTOS, Andrés de La Oliva. GIMÉNEZ, Ignacio Díez-Picazo. Derecho procesal civil: el proceso de declaración. Conforme a la ley 1/2000, de 7 de enero de enjuciamiento 
Revista Eletrônica de Direito Processual - REDP.

Rio de Janeiro. Ano 11. Volume 18. Número 2. Maio a Agosto de 2017

Periódico Quadrimestral da Pós-Graduação Stricto Sensu em Direito Processual da UERJ

Patrono: José Carlos Barbosa Moreira. ISSN 1982-7636. pp. 297-326

www.redp.uerj.br

pode-se dizer, numa primeira análise, que o conteúdo do objeto do processo é composto pela causa de pedir, pelo pedido e pelas partes (art. 337, §2. ${ }^{\circ}, \mathrm{CPC}$ ). Porém, trata-se de uma visão limitada, na medida em que também as exceções substanciais são componentes essenciais do objeto do processo, notadamente quando se está diante da resolução do problema dos limites de atuação de ofício do juiz no processo civil.

\section{Definição conceitual das exceções substanciais}

A primeira dificuldade teórica relativa às denominadas "exceções substanciais" reside na falta de precisão que o termo "exceção" recebe no direito moderno. Comumente, conforme afiança Serpa Lopes, ele é utilizado para designar qualquer meio empregado pelo réu no sentido de "escapar dos efeitos da demanda" 25 . Um mergulho na história do conceito jurídico de exceção indo até o direito romano, no entanto, poderá prestar um significativo auxílio para que se torne possível compreender como, do direito atual, o conceito foi sendo baralhado para significar, simplesmente defesa do réu.

A exceptio no direito romano surge com a introdução do procedimento per formulas $^{26}$, assim denominado por estar caracterizado pela fórmula (um esquema normalmente redigido na forma escrita) ${ }^{27}$ que o magistrado (pretor) entregava ao autor para que pudesse fazê-la valer frente ao juiz (iudex $)^{28}$. Cabe lembrar que, nesse estágio do

civil. Madrid: Editorial centro de estudios ramón areces S.A, 2000, p. 43. DOMÍNGUEZ, Valentín Cortés. SENDRA, Vicente Gomeno. CATENA. Víctor Moreno. Derecho Procesal civil. Madrid: Editorial Colex, 1997, p. 120. RAMOS, Manuel Ortells. Derecho procesal civil. Navarra: Aranzadi Editorial, 2000, p. 254. PENALVA, Ernesto Pedraz. El objeto del proceso civil. Madrid: Edit. Consejo general del poder judicial, 1996, p. 45.

${ }^{25}$ SERPA LOPES, Miguel Maria. Exceções substanciais: exceção de contrato não cumprido (exceptio non adimpleti contractus). Rio de Janeiro: Freitas Bastos, 1959, p. 11.

${ }^{26}$ MILONE, Filippo. La exceptio doli (generalis): studio di diritto romano. Napoli: Riccardo Marghieri di Gius, 1882 , p. 6.

${ }^{27}$ COSTA, Emillio. Profilo storico del processo civile romano. Roma: Athenaeum, 1918, p. 28.

${ }^{28}$ ALSINA, Hugo. Defensas y excepciones. Buenos Aires: Ediciones juridicas europa-america - EJEA, 1958, p. 14. A introdução do processo formulário ocorreu entre 149 e 126 a.C., por força da Lex Aebutia. Gradualmente, com o advento da Lex Julia iudiciorum publicorum e da Lex Julia iudiciorum privatorum, por volta de 17 a.C., o processo da Legis Actiones foi praticamente abolido, persistindo, somente, nas ações de damnum infectum e nos processos que se desenvolviam no tribunal dos centúnviros. Nesse sentido, COSTA, Emillio. Profilo storico del processo civile romano. Roma: Athenaeum, 1918, p. 29. GIORDANI, Mário Curtis. Processo civil romano: noções elementares. São Paulo: Idéias e Letras, 2010, p. 88. Segundo Villey, o advento do processo per formulas decorreu do desenvolvimento comercial em Roma, que trouxe consigo o fato de numerosos estrangeiros, itálicos, helenos, terem recebido a cidadania. Eles, "vêm povoar a cidade de Roma e traficam com os romanos no rico mercado em que se tornou a capital do Império. Têm de facto conflitos jurídicos entre si e com os romanos. Procuram o pretor responsável pela ordem da cidade. Que fará este? Ele não pode organizar o litígio dum peregrino segundo as formas que não são acessíveis senão aos romanos. 
Revista Eletrônica de Direito Processual - REDP.

Rio de Janeiro. Ano 11. Volume 18. Número 2. Maio a Agosto de 2017

Periódico Quadrimestral da Pós-Graduação Stricto Sensu em Direito Processual da UERJ

Patrono: José Carlos Barbosa Moreira. ISSN 1982-7636. pp. 297-326

WWW.redp.uerj.br

processo civil romano, havia uma divisão do processo em duas fases: a fase in iure, desenvolvida perante o pretor, e a fase apud iudicem, que se desenvolvia perante o iudex. Com efeito, pretor emitia uma instrução escrita ao iudex para um ulterior procedimento e para a decisão definitiva da causa mediante a sentença ${ }^{29}$.

Nesses termos, o processo in iure iniciava com a edition actiones mediante a qual o autor indicava a sua actio que entendia fazer valer contra o réu. Diante da edition actiones do autor, o réu poderia opor uma absoluta negação dos fatos que constituíam o pressuposto da sua pretensão ou, ainda, reconhecer a existência dos fatos e contrapor outros, os quais valeriam para elidir as consequências jurídicas pretendidas pelo autor. Fazendo isso, o réu postulava ao magistrado que os fatos por ele alegados fossem levados em conta por meio de uma exceção inserida na fórmula, acerca da qual teria lugar o iudicium ${ }^{30}$. Consequentemente, o magistrado indicava os fatos alegados pelo réu na fórmula no formato de exceção, vale dizer, "exceptuando y excluyendo de lo que ha fijado en la intentio, el caso en que, por

Resolverá imitando o mais possível o processo romano; suprimindo apenas as formalidades arcaicas e inúteis do velho direito quiritário, que não têm mais aqui razão para serem respeitadas; inspirando-se, sempre que possível, nos costumes mais práticos da Grécia, nos hábitos dos próprios peregrinos. O pretor acolhe, pois, o estrangeiro no seu tribunal; dar-lhe-á um juiz como faz ao cidadão romano. E (eis onde se faz sentir a influência grega, como trabalhos recentes o demonstraram), convidará os litigantes a inscreverem, numa fórmula escrita, as suas pretensões exactas das quais o juiz deverá confirmar o fundamento e as condenações precisas, cuja conclusão lhe é pedida" (VILLEY, Michel. Direito romano. Tradução de Fernando Couto. Porto: Editora Resjuridica, 1991, pp. 58-59).

${ }^{29}$ SCIALOJA, Vittorio. Procedura civile romana; esercizio e difesa dei diritti. Roma: Anonima Romana, 1936, p. 110. Mais precisamente, Scialoja define a fórmula como "un'istruzione scritta colla quale il magistrato nomina il giudice, e fissa gli elementi sui quali questi dovrà fondare il suo giudizio, dandogli anche il mandato, più o meno determinato, per la condanna eventuale nella sentenza, o per l'assoluzione" (SCIALOJA, Vittorio. Procedura civile romana; esercizio e difesa dei diritti. Roma: Anonima Romana, 1936, p. 111). A formulaera composta pela demonstratio, intentio, adiudicatio e condemnatio. Segundo a lição de Scialoja, "La demonstratio, come indica la parola stessa, è in sostanza una enunciazione del fatto che forma la base della lite. Si badi, perì, di non incorrere in un errore, a cui può dar pretesto il modo in cui si esprime Gaio; fatti enunciati nella demostratio in un modocosì postiivo, sembrano affermati dal pretore al giudice e posti quasi fuori d'ogni ulteriore contestazione e dubbio, ma non è così; il giudice deve ricercare primieramente si il fatto dedotto nella demonstratio sia vero, ricerca che viene appunto indicata nella parola quod colla quale incomincia la formula (...) L'intentio, dunque, è quella parte della formula, nella quale l'attore conclude, ossia, espone succintamente la sua domanda (...) il giudice deve attribuire la cosa, o parte della cosa, o diritti sulla cosa ad alcuno dei litiganti, attribuzione che gli è demandata mediante questa parte speciale della formula, che è l'adiudicatio (...) La condanna, dunque, è l'ultima parte della formula, ed è quella colla quale si giunge ad un risultato essecutivo; il giudice, si paret tutto ciò che è contenuto nella demonstratio e nell'intentio, condanna, si non paret, assolve; e deve condannare a tutto ciò a cui è stato delegato dal magistrato". Além disso, como destaca Scialoja, "una parte della formula, che non è menizonata da Gaio, ma anche è presupposta, è la nomina del giudice, al quale, come sappiamo, si rivolge il contenuto della formula" (SCIALOJA, Vittorio. Procedura civile romana; esercizio e difesa dei diritti. Roma: Anonima Romana, 1936, pp. 111-113).

${ }^{30}$ MILONE, Filippo. La exceptio doli (generalis): studio di diritto romano. Napoli: Riccardo Marghieri di Gius, 1882 , p. 31. 
Revista Eletrônica de Direito Processual - REDP.

Rio de Janeiro. Ano 11. Volume 18. Número 2. Maio a Agosto de 2017

Periódico Quadrimestral da Pós-Graduação Stricto Sensu em Direito Processual da UERJ

Patrono: José Carlos Barbosa Moreira. ISSN 1982-7636. pp. 297-326

www.redp.uerj.br

ejemplo, hubiese ocurrido dolo, violencia o cualquier otro hecho alegado por el defensor",31.

Com isso, objetivava-se mitigar o rigor do direito civil, evitando que uma sentença justa em

direito, fosse injusta em juízo de equidade, na medida em que o direito civil somente levava em conta a forma externa dos atos, não considerando os vícios da vontade ${ }^{32}$. Didaticamente, a fórmula da exceção pode assumir a seguinte veste, como exemplifica Michel Villey: "parece que X deve mil. A menos que tenha havido dolo do credor. Juiz, condena X a pagar mil ao litigante $Y$,33.

Essa breve alusão ao direito romano deixa suficientemente claro que o termo exceção nasceu como um meio de neutralizar o direito do autor, situando-se no plano do direito material, e não do processo. Ademais, diferenciava-se a exceção da mera negação dos fatos alegados pelo autor. Foi no processo civil moderno que, segundo Mortara, todos os meios dos quais o réu se vale para a rejeição da demanda do autor passaram a receber o nome de exceção $^{34}$. Quem primeiramente combateu de modo incisivo referida simplificação operada em relação ao uso do termo exceção, no bojo do processo, foi Oskar Bülow. Após um profundo estudo das exceções no direito romano, o jurista alemão inicia o capítulo oitavo da sua obra essencial para o estudo do direito processual civil, reafirmando que a exceptio, assim como a actio, "pertenecen, por su contenido, al derecho material exclusivamente”35. Para ele, toda as exceções fariam referência somente à "relación litigiosa material (la res in iudicium deducta)”, e nunca à forma da demanda ou do processo $^{36}$. No fundo, sua teoria

\footnotetext{
${ }^{31}$ ORTOLAN, M. Compendio del derecho romano. Buenos Aires: Atalaya, 1947, p. 177. Desse modo, "come le formule delle azioni ordinarie, così anche le formule delle più comuni eccezioni erano proposte nell'editto, ed erano scritte nell'ultima parte; sicchè, mentre, come vederemo in seguito, l'attore domandava: mi si conceda questa tale azione, e la designava addirittura col dito sull'editto, il convenuto diceva: io voglio che si inserisca questa eccezione, indicandola allo stesso modo" (SCIALOJA, Vittorio. Procedura civile romana; esercizio e difesa dei diritti. Roma: Anonima Romana, 1936, p. 118).

${ }^{32}$ De acordo com Alsina, "fueran introducidas por los pretores para mitigar los rigores del derecho civil, evitando que una sentencia justa en derecho, fuera injusta en equidad, pues el derecho civil sólo tenía en cuenta la forma externa de los actos y no consideraba los vicios de la voluntad; bastaba que se hubieran cumplido los requisitos de la estipulatio sin que le restara validez la circunstancia de que el consentimiento se hubiera obtenido por error, dolo o violencia. La excepción, que el magistrado incluía en la fórmula a requerimiento del demandado, autorizaba al juez por razones de equidad, a tener en cuenta esas circunstancias" (ALSINA, Hugo. Defensas y excepciones. Buenos Aires: Ediciones juridicas europa-america - EJEA, 1958, p. 17).

${ }^{33}$ VILLEY, Michel. Direito romano. Tradução de Fernando Couto. Porto: Editora Resjuridica, 1991, p. 62.

${ }^{34}$ MORTARA, Lodovido. Manuale della procedura civile. Volume primo. Torino: Unione TipograficoEditrice Torinense, 1910, p. 26.

${ }^{35}$ BÜLOW, Oskar. La teoria de las excepciones procesales y los presupuestos procesales. Buenos Aires: EJEA, 1964, p. 252.

${ }^{36}$ BÜLOW, Oskar. La teoria de las excepciones procesales y los presupuestos procesales. Buenos Aires: EJEA, 1964, p. 252.
} 
Revista Eletrônica de Direito Processual - REDP.

Rio de Janeiro. Ano 11. Volume 18. Número 2. Maio a Agosto de 2017

Periódico Quadrimestral da Pós-Graduação Stricto Sensu em Direito Processual da UERJ

Patrono: José Carlos Barbosa Moreira. ISSN 1982-7636. pp. 297-326

www.redp.uerj.br

busca evidenciar que o conceito de exceção processual é imprestável constituindo "un esquema vacío, carente de fundamento" ${ }^{\prime 37}$, devendo ser abandonada essa expressão e substituída pela expressão pressupostos processuais $^{38}$, seara pertinente, pois, ao direito público e que escaparia do âmbito de disponibilidade das partes, razão pela qual poderiam ser analisados de ofício pelo juiz ${ }^{39}$. Essa distinção terminológica é extremamente importante, embora nem sempre seja observada pela doutrina ${ }^{40}$.

\section{Exceções substanciais como limitadoras da atuação de ofício do juiz}

Partindo das lições anteriores, pode-se dizer que o termo exceção substancial é, de certo modo, uma redundância, na medida em que, na sua gênese, o conceito de exceção está atrelado inevitavelmente ao direito material. No plano das defesas substanciais, costuma-se distinguir a defesa direta e a defesa indireta. Na primeira, o réu limita-se a negar os fatos alegados na demanda ou as consequências jurídicas pleiteadas pelo autor, ao passo que, na segunda ele invoca fatos novos tendentes a influir sobre a existência ou vida do direito afirmado pelo autor ${ }^{41}$. Nessa segunda hipótese enquadram-se as chamadas exceções

${ }^{37}$ BÜLOW, Oskar. La teoria de las excepciones procesales y los presupuestos procesales. Buenos Aires: EJEA, 1964. p. 290. Tradução livre: “um esquema vazio, carente de fundamento”.

${ }^{38}$ BÜLOW, Oskar. La teoria de las excepciones procesales y los presupuestos procesales. Buenos Aires: EJEA, 1964. p. 302.

${ }^{39}$ BÜLOW, Oskar. La teoria de las excepciones procesales y los presupuestos procesales. Buenos Aires: EJEA, 1964. pp. 296-297. No fundo, a posição defendida por Bülow na obra que serviu de base para a formação da ciência processual tinha o objetivo mais profundo de conferir maiores poderes ao juiz, para que este pudesse, enqunato representante do Estado, agir de ofício no tocante às questões pertinentes à relação jurídica processual. Verifica-se, aqui, a estreita vinculação de Bülow com o movimento do direito livre, o que ficaria ainda mais evidenciado na sua obra posterior denominada Lei e Magistratura (Gesetz und Richteramt), publicada em 1885 .

${ }^{40}$ Apenas para exemplificar, pode-se mencionar o pensamento de Eduardo Couture, o qual refere que "en múltiples casos, la excepción es un medio legal de denunciar al juez la falta de presupuestos necesarios para la validez del juicio". Justiça seja feita, porém. Couture, apesar de pecar na precisão terminológica, aduz que "los presupuestos procesales no necesitan excepción y pueden hacerse valer de oficio por el juez" (COUTURE, J. Eduardo. Fundamentos del derecho procesal civil. Segunda edición ampliada y actualizada. Buenos Aires: Editorial Depalma, 1951, p. 51).

${ }^{41}$ DINAMARCO, Candido Rangel. Instituições de direito processual civil. $6^{\text {a }}$ ed. São Paulo: Malheiros, 1999. pp. 334-335. LOPES DA COSTA, Alfredo de Araújo. Direito processual civil brasileiro (Código de 1939). V. 2. Rio de Janeiro: José Konfino, 1946, p. 225. No direito romano, segundo Filipo Milone, as defesas de mérito poderiam ser ordenadas em três classes: "1. Difese consistenti nel negare che il diritto dello attore abbia mai avuto esistenza, sia impugnando il fatto materiale che vi serve di fondamento (traditio, stipulatio ecc.), sia impugnando la validità giuridica del fatto medesimo (per dementia, minor aesta ecc.). E queste vengon dette negazione semplici o assolute. 2. Difese dirette a sostenere che il diritto dell'attore per un fatto susseguente abbia cessato di esistere: dove al diritto da prima esistito si oppone un fatto che è venuto a distruggerlo (p. e. usucapio, solutio), e con ciò se non si nega l'esistenza sua originaria, pur si nega l'attuale. E soglion queste chiamarsi negazioni relative o qualificate. 3. Difense con le quali, senza negare il diritto dell’attore, anzi ammettendolo, vi si contrappone un altro diritto che viene ad eliderlo. Qui il diritto dell'attore si suppone nato 
Revista Eletrônica de Direito Processual - REDP.

Rio de Janeiro. Ano 11. Volume 18. Número 2. Maio a Agosto de 2017

Periódico Quadrimestral da Pós-Graduação Stricto Sensu em Direito Processual da UERJ

Patrono: José Carlos Barbosa Moreira. ISSN 1982-7636. pp. 297-326

www.redp.uerj.br

substanciais, as quais têm, como primeira característica, pressupor a alegação de fatos novos pelo réu. Afirma-se, então, que "o réu sai para fora do terreno em que o autor se colocou e socorre de fatos diversos daqueles em que se funda a petição ${ }^{42}$.

O principal elemento do conceito de exceção substancial está na impossibilidade de o juiz conhecer de ofício dos fatos alegados pelo réu. O âmago do termo exceção, desse modo, estaria na impossibilidade do juiz dela conhecer sem provocação da parte ${ }^{43}$. Avançando no tema, porém, depara-se com uma subdivisão doutrinária no âmbito das exceções substanciais, segundo a qual nem sempre que o réu alega um fato novo como fundamento de sua defesa se estaria diante de uma exceção propriamente dita. Chiovenda, nesses termos, fala em exceção em sentido impróprio quando "si ottiene il rigetto della domanda perchè l'azione o non è mai nata o è venuta meno anteriormente alla eccezione" ${ }^{44}$. Muito similar é a lição de José Alberto dos Reis, responsável por agrupar os fatos extintivos em duas classes, quais sejam, (i) a dos fatos que excluem por si mesmo o direito do autor e a (ii) dos fatos que somente excluem o direito por vontade do réu ${ }^{45}$. Também Hugo Alsina distingue os fatos impeditivos que obstam o nascimento da relação jurídica daqueles que somente afetam a sua eficácia ${ }^{46}$.

\footnotetext{
ed esistente, ma si sostiene che per un diritto contrario, sorto insieme con esso o di poi, non debba conseguire il suo efetto. E tali difese costituiscono le eccezioni propriamente dette" (MILONE, Filippo. La exceptio doli (generalis): studio di diritto romano. Napoli: Riccardo Marghieri di Gius, 1882, pp. 1-2).

${ }^{42}$ REIS, José Alberto dos. Código de processo civil anotado. Voluma II. Artigos 487 a $549.4^{\mathrm{a}}$ ed. Coimbra: Coimbra, 1985, p. 24.

${ }^{43}$ LOPES DA COSTA, Alfredo de Araújo. Direito processual civil brasileiro (Código de 1939). V. 2. Rio de Janeiro: José Konfino, 1946, p. 227. Conforme Serpa Lopes, "enquanto, nas objeções, o réu pode assumir uma atitude inteiramente passiva, ou limitar-se a uma contra-prova, e, quando necessário, ir mais além, pois, conforme as circunstâncias, qualquer dessas atitudes pode ser apta a proporcionar-lhe um resultado favorável; enquanto nas objeções, em dados casos, é possível uma intervenção ex ofício do Juiz tendente ao esclarecimento da prova do mérito, nas exceções tudo depende do movimento ativo do réu, e elas, de modo nenhum, podem ser suscitadas ex officio pelo Juiz, razão pela qual tal circunstâncias influi como um dos motivos para se excluir da categoria das exceções os casos de nulidade absoluta. Nas exceções substanciais, o poder do Juiz é limitado; tudo depende da manifestação livre do demandado. Na exceção em sentido técnico, é a arguição da parte que cria para o juiz o poder de decidi-la" (SERPA LOPES, Miguel Maria. Exceções substanciais: exceção de contrato não cumprido (exceptio non adimpleti contractus). Rio de Janeiro: Freitas Bastos, 1959, p. 93).

${ }^{44}$ CHIOVENDA, Giuseppe. Sulla "eccezione". Saggi di diritto processuale civile. Volume primo. Roma: Società editrice Foro Italiano, 1930, p. 151.

${ }^{45}$ REIS, José Alberto dos. Código de processo civil anotado. Voluma II. Artigos 487 a $549.4^{\mathrm{a}}$ ed. Coimbra: Coimbra, 1985, p. 33.

${ }^{46}$ ALSINA, Hugo. Defensas y excepciones. Buenos Aires: Ediciones juridicas europa-america - EJEA, 1958, p. 98.
} 
Revista Eletrônica de Direito Processual - REDP.

Rio de Janeiro. Ano 11. Volume 18. Número 2. Maio a Agosto de 2017

Periódico Quadrimestral da Pós-Graduação Stricto Sensu em Direito Processual da UERJ

Patrono: José Carlos Barbosa Moreira. ISSN 1982-7636. pp. 297-326

www.redp.uerj.br

Isso quer dizer que nem toda defesa do réu consistente em alegar fatos novos tem a mesma característica jurídica. Um bom exemplo das exceções em sentido impróprio seria a alegação de pagamento. Quando o réu alega o pagamento ele não está neutralizando o direito do autor, mas afirmando a sua inexistência, na medida em que o inadimplemento constitui elemento do conjunto de fatos que constitui a causa de pedir deduzida pelo autor. Daí se afirmar, inclusive, que a exceção de pagamento não seria, na verdade, uma autêntica exceção substancial, mas defesa direta de mérito ${ }^{47}$.

\section{Exceções substanciais como contradireitos do réu}

$\mathrm{Na}$ perspectiva anteriormente trabalhada torna-se possível referir que o sentido autêntico do termo exceção substancial (eccezione in senso proprio) é de um contradireito do réu. Isso quer dizer que, arguindo uma exceção, o demandado opõe ao direito do autor um direito seu, fundando-se, pois, em direito próprio e independente ${ }^{48}$. $\mathrm{O}$ fato impeditivo ou modificativo é alegado pelo réu como fundamento da exceção assim como o fato constitutivo é alegado como fundamento da demanda ${ }^{49}$. Em tais casos, quando o réu alega um fato

\footnotetext{
${ }^{47}$ SILVA, Ovídio A. Baptista da. Curso de processo civil, volume 1: processo de conhecimento. $7^{\mathrm{a}}$ ed., Rio de Janeiro: Forense, 2005, p. 160. Alguns autores enquadram o pagamento na categoria das objeções substanciais, que diriam respeito justamente àquelas questões de direito material passíveis de conhecimento de ofício pelo juiz. O cerne da objeção, desse modo, estaria em atingir o próprio direito, e não simplesmente neutralizar sua eficácia. Nesse sentido, "o acolhimento da objeção substancial não toca na eficácia da pretensão, mas, em verdade, reconhece a sua extinção. $\mathrm{O}$ pagamento, a decadência legal e a nulidade do negócio jurídico são exemplos de objeção substancial, que, portanto, podem ser conhecidas de ofício pelo órgão julgador, independentemente de alegação pela parte interessada" (MONTEIRO, André Luís. O regime das exceções no direito processual civil brasileiro: de mérito e processual, direta e indireta, dilatória e peremptória, exceção e objeção. Revista de processo. Ano 38. Volume 216. São Paulo: Revista dos Tribunais, 2013, p. 53).

${ }^{48}$ SERPA LOPES, Miguel Maria. Exceções substanciais: exceção de contrato não cumprido (exceptio non adimpleti contractus). Rio de Janeiro: Freitas Bastos, 1959, p. 16.

${ }^{49}$ CAPPELLETTI, Mauro. L'eccezione come controdiritto del convenuto. Rivista di diritto processuale. v. XVI. Padova: CEDAM, 1961, p. 268.
} 
Revista Eletrônica de Direito Processual - REDP.

Rio de Janeiro. Ano 11. Volume 18. Número 2. Maio a Agosto de 2017

Periódico Quadrimestral da Pós-Graduação Stricto Sensu em Direito Processual da UERJ

Patrono: José Carlos Barbosa Moreira. ISSN 1982-7636. pp. 297-326

WWW.redp.uerj.br

impeditivo $^{50}$, modificativo ${ }^{51}$ ou extintivo ${ }^{52} \mathrm{e}$, com isso, visa a neutralizar o direito afirmado pelo autor, suspendendo-o ou cobrindo sua eficácia ${ }^{53}$, formula uma declaração de vontade consubstanciada em querer exercer um direito $\operatorname{seu}^{54}$, cujo conhecimento de ofício pelo juiz, salvo nos casos expressamente previstos em lei, é vedado ${ }^{55}$, e que, em regra, também poderia ser deduzido de forma autônoma ${ }^{56}$. Diversos exemplos avultam a respeito da matéria, como a exceção de domínio, a exceção de usucapião, a exceção de retenção por benfeitorias, a exceção de compensação, a exceção de contrato não cumprido, a exceptio plurium concubentium $^{57}$, a exceção de prescrição, dentre outras.

\footnotetext{
${ }^{50}$ Conforme Cleanto Siqueira "por meio dos fatos impeditivos pretende o réu como que obstaculizar a projeção de efeitos dos fatos trazidos pelo autor. Não nega, o demandado, seja o autor titular de um direito subjetivo. Pretende, apenas, retardar o seu ingresso no patrimônio jurídico do demandante.Veja-se o caso da clássica exceptio inadim- pletis contractos nos contratos bilaterais: ao alegar a existência de obrigação que deveria ser cumprida pelo autor, o réu conseguirá, tão-somente, retardar a eficácia dos fatos trazidos na postulação inicial.Tão logo seja adimplida a obri- gação submetida ao seu adversário, deverá o réu sujeitar-se aos efeitos do seu comportamento" (SIQUEIRA, Cleanto Guimarães. A defesa no processo civil as exceções substanciais no processo de conhecimento. $3^{\mathrm{a}}$ ed. São Paulo: Saraiva, 2008, p. 276).

$51 \mathrm{Na}$ categoria dos fatos modificativos "estão os fatos, apresentados pelo demandado, a partir dos quais procura tão-somente alterar as conseqüências jurídicas daqueles trazidos pelo autor. Como exemplo, citemos o fato da existência de crédito compensável, alegada na chamada exceção de compensação: não se trata, regra geral, de extinguir o direito de crédito, e sim de reduzir a expressão do bem jurídico cuja tutela pretende o autor. No mesmo diapasão encontra-se a alegação de culpa concorrente, com a qual o réu, normalmente em demandas decorrentes de delitos de trânsito, procura demonstrar ter o autor contribuído, igualmente, com sua conduta displicente, para o evento" (SIQUEIRA, Cleanto Guimarães. A defesa no processo civil as exceções substanciais no processo de conhecimento. $3^{\mathrm{a}}$ ed. São Paulo: Saraiva, 2008, p. 276).

${ }^{52}$ Os fatos extintivos são aqueles "cuja eficácia (=efeitos produzidos) consiste no aniquilamento do direito subjetivo de que se julga titular o autor" (SIQUEIRA, Cleanto Guimarães. A defesa no processo civil as exceções substanciais no processo de conhecimento. $3^{\mathrm{a}}$ ed. São Paulo: Saraiva, 2008, p. 275).

${ }^{53}$ No dizer de Pontes de Miranda, "a exceção supõe direito, que se exerça por meio dela; daí a parecença com a ação. O que as distingue é apenas o estar a exceção em contraposição a algum direito ou efeito dele, sem no excluir, nem no modificar. O mesmo direito pode produzir ação, ou ações, e exceções. Porém seria erro dizerse que pode usar de exceção aquele que tem ação. Ora, esse mudar de posição não é arbitrário; depende do direito material. Nem todas as ações se podem intentar ope exceptionis" (PONTES DE MIRANDA, Francisco Cavalcanti. Tratado de direito privado. Tomo VI. Rio de Janeiro: Borsoi, 1955, p. 6).

${ }^{54} \mathrm{Na}$ tentativa de delimitar as exceções substanciais em sentido próprio Alsina afirma que "habrá excepción cuando ella suponga el ejercicio de un derecho subjetivo o cuando pudiera significar un perjuicio económico o moral, porque es evidente que en tales casos el único que puede decidirlo es el propio interesado" (ALSINA, Hugo. Defensas y excepciones. Buenos Aires: Ediciones juridicas europa-america - EJEA, 1958, p. 96).

${ }^{55}$ Segundo Chiovenda "questa necessità della isanza del convenuto non è che la manifestazione esteriore e tangibile dell'intima natura di diritto che le eccezioni possiedono" (CHIOVENDA, Giuseppe. Sulla "eccezione". Saggi di diritto processuale civile. Volume primo. Roma: Società editrice Foro Italiano, 1930, p. $154)$.

${ }^{56}$ Sobre a aptidão das matérias objeto de exceção substancial constituírem objeto de demanda autônoma, ver SICA, Heitor Vitor Mendonça. $O$ direito de defesa no processo civil brasileiro: um estudo sobre a posição do réu. São Paulo: Atlas, 2011, p. 140 e seguintes.

${ }^{57}$ Afirma Cleanto Guimarães Siqueira que "a clássica exceção substancial no direito de família, para as ações de investigação de paternidade, é a exceptio plurium concubentium, na qual o réu - indigitado pai -, sem negar a ocorrência dos fatos do art. 1.605 do Código Civil de 2002 (começo de prova por escrito, proveniente dos pais, conjunta ou separada- mente, e veementes presunções resultantes de fatos já certos), sustenta ter havido
} 
Revista Eletrônica de Direito Processual - REDP.

Rio de Janeiro. Ano 11. Volume 18. Número 2. Maio a Agosto de 2017

Periódico Quadrimestral da Pós-Graduação Stricto Sensu em Direito Processual da UERJ

Patrono: José Carlos Barbosa Moreira. ISSN 1982-7636. pp. 297-326

www.redp.uerj.br

No que tange à delimitação dos poderes do juiz, aplicam-se aos fatos constitutivos dos contradireitos - cujo caráter dúplice é inegável, na medida em que, igualmente, se apresentam como modificativos, impeditivos ou extintivos em relação ao direito do autor as mesmas considerações pertinentes aos fatos constitutivos alegados pelo autor. Assim, se por um lado, "l'eccezione-atto, al pari della domanda, è creativa del dovere del giudice di decidere sul mérito dell'eceezione-rapporto "58 , por outro, o juiz não poderá conhecê-los de ofício $^{59}$. Afinal, como bem destacou Guasp, a exceção pressupõe um direito subjetivo cujo exercício é reservado à vontade do seu titular ${ }^{60}$.

\section{Exceções substanciais, ampliação e formação dinâmica do objeto do processo}

Bastante controversa é a repercussão das exceções substanciais no tocante à ampliação do objeto do processo. Diversos autores entendem que as defesas substanciais do réu não ampliam o objeto do processo, ao passo que uma parcela bastante reduzida da doutrina processual enxerga nas exceções substanciais a possibilidade de modificação do objeto litigioso.

Com efeito, a grande maioria dos doutrinadores entende que é o autor que "c"est le demandeur qui fixe les limites objectives de l'action" ${ }^{\prime \prime 1}$. Com efeito, quer se defenda por meio de contestação simples, quer invocando defesas substanciais de mérito, o réu somente busca afastar o pedido contra si formulado pelo autor, nada pedindo ${ }^{62}$. Assim, não estando a

outros consortes na vida da mãe do autor, no período legal da concepção" (SIQUEIRA, Cleanto Guimarães. $A$ defesa no processo civil as exceções substanciais no processo de conhecimento. $3^{\mathrm{a}}$ ed. São Paulo: Saraiva, 2008, p. 352).

58 CAPPELLETTI, Mauro. L'eccezione come controdiritto del convenuto. Rivista di diritto processuale. $\mathrm{v}$. XVI. Padova: CEDAM, 1961, p. 268.

${ }^{59}$ CAPPELLETTI, Mauro. La testimonianza della parte nel sistema dell'oralità: contributo alla teoria della utilizzazione probatória del sapere delle parti nel processo civile. Parte prima. Milano: Dott. A. Giuffrè Ditore, 1962 , p. 346.

${ }^{60}$ GUASP, Jaime. Juez y hechos en el proceso civil: una crítica del derecho de disposición de las partes sobre el material de hecho del proceso. Barcelo: Bosch, 1943, p. 119. Nas palavras de Guasp, "no es que la excepción constituya un contradeerecho porque se funda en hechos que el Juez no puede nunca conocer de oficio, sino al revés, no puede el Juez conocerlos porque la excepcioón supone precisamente el ejercicio de un derecho subjetivo y resrvado, por consiguiente, a la voluntad de su titular" (GUASP, Jaime. Juez y hechos en el proceso civil: una crítica del derecho de disposición de las partes sobre el material de hecho del proceso. Barcelo: Bosch, 1943, p. 119).

${ }^{61}$ HABSCHEID, Walter. L'action en justice. In: Droit judiciaire privé suiss. Genève: Ed. Liberairée de L’Université Georgetcie S.A, 1981, p. 257.

${ }^{62}$ SILVA, Ovídio A. Baptista da. Curso de processo civil, volume 1: processo de conhecimento. $7^{\mathrm{a}}$ ed., Rio de Janeiro: Forense, 2005, p. 154. 
Revista Eletrônica de Direito Processual - REDP.

Rio de Janeiro. Ano 11. Volume 18. Número 2. Maio a Agosto de 2017

Periódico Quadrimestral da Pós-Graduação Stricto Sensu em Direito Processual da UERJ

Patrono: José Carlos Barbosa Moreira. ISSN 1982-7636. pp. 297-326

www.redp.uerj.br

formular pedido em sentido técnico, não estaria a ampliar o thema decidendum ${ }^{63}$. Somente quando reconvém é que estaria formulando outra pretensão processual em face do autor e, consequentemente, ampliando o objeto do processo $^{64}$. Isso, porém, não significaria que as defesas substanciais de mérito não teriam repercussão no âmbito da cognição judicial. Tais questões teriam o condão de ampliar a matéria de discussão e de resolução no processo ${ }^{65}$. Nesse sentido, Dinamarco, após negar relevância ao comportamento do demandando quanto ao objeto do processo, refere que suas alegações irão constituir objeto do conhecimento do juiz, o qual é composto por toda a massa de questões que no processo surgirem, venham de onde vierem ${ }^{66}$.

$\mathrm{Na}$ verdade, poucos são os autores que consideram as exceções substanciais como integrantes do objeto litigioso. No direito espanhol, Andrés de La Oliva Santos e Ignácio Díez-Picazo Giménez entendem que, se o réu alega fatos novos o objeto do processo pode ampliar-se repercutindo em questões como a litispendência e a coisa julgada ${ }^{67}$. No direito brasileiro, quem melhor se ocupou do tema, defendendo que as defesas substanciais compõem o objeto litigioso, foi Fredie Didier. Para ele, quando o réu, em sua defesa, exerce um contradireito, "acrescenta ao processo a afirmação de um direito que comporá o objeto litigioso da decisão" ${ }^{" 68}$. Nesse caso, conforme o jurista baiano, o mérito do processo será a soma de dois binômios: "afirmação do direito feita pelo demandante (pedido + causa de

\footnotetext{
${ }^{63}$ BARBOSA MOREIRA, José Carlos. Limites objetivos da coisa julgada no sistema do código de processo civil. Temas de direito processual: primeira série. São Paulo: Saraiva, 1977, p. 91. No mesmo sentido, RAMOS, Manuel Ortells. Derecho procesal civil. Navarra: Aranzadi Editorial, 2000, p. 255. DOMÍNGUEZ, Valentín Cortés. SENDRA, Vicente Gomeno. CATENA. Víctor Moreno. Derecho Procesal civil. Madrid: Editorial Colex, 1997, p. 120. SILVA, Ovídio A. Baptista da. Curso de processo civil, volume 1: processo de conhecimento. $7^{\mathrm{a}}$ ed., Rio de Janeiro: Forense, 2005, p. 154.

${ }^{64}$ BARBOSA MOREIRA, José Carlos. Limites objetivos da coisa julgada no sistema do código de processo civil. Temas de direito processual: primeira série. São Paulo: Saraiva, 1977, p. 91. HABSCHEID, Walter. L'action en justice. In: Droit judiciaire privé suiss. Genève: Ed. Liberairée de L'Université Georgetcie S.A, 1981, p. 257. RIBEIRO, Darci Guimarães. Objeto do processo e objeto o debate: dicotomia essencial para uma adequada compreensão do novo CPC. Desvendando o novo CPC. Darci Guimarães Ribeiro, Marco Félix Jobim (organizadores). Porto Alegre: Livraria do Advogado, 2015, p. 32.

${ }^{65}$ RAMOS, Manuel Ortells. Derecho procesal civil. Navarra: Aranzadi Editorial, 2000, p. 254.

${ }^{66}$ DINAMARCO, Candio Rangel. O conceito de mérito em processo civil. Revista de processo. v. 34. São Paulo: Revista dos Tribunais, 1984, pp. 34-35.

67 SANTOS, Andrés de La Oliva. GIMÉNEZ, Ignacio Díez-Picazo. Derecho procesal civil: el proceso de declaración. Conforme a la ley $1 / 2000$, de 7 de enero de enjuciamiento civil. Madrid: Editorial centro de estudios ramón areces S.A, 2000, p. 47.

${ }^{68}$ DIDIER JÚNIOR, Fredie. Contradireitos, objeto litigioso do processo e improcedência. Revista de Processo. v.38, n.223. São Paulo: Revista dos Tribunais, 2013, p. 93.
} 
Revista Eletrônica de Direito Processual - REDP.

Rio de Janeiro. Ano 11. Volume 18. Número 2. Maio a Agosto de 2017

Periódico Quadrimestral da Pós-Graduação Stricto Sensu em Direito Processual da UERJ

Patrono: José Carlos Barbosa Moreira. ISSN 1982-7636. pp. 297-326

www.redp.uerj.br

pedir) + afirmação do contradireito feita pelo demandando (pedido relativo à exceção substancial + causa dessa exceção substancial)" ${ }^{\prime 69}$.

A leitura de alguns processualistas italianos pode trazer subsídios para reforçar a tese de Didier. Francesco Carnelutti, apesar de combater a categoria dos contradireitos, proficuamente defendida por Chiovenda e por Mauro Cappelletti, entendia que a exceção deduzida pelo réu teria o condão de determinar "un alargamento dell'area del processo" ao estender "il giudizio a fatti e a fattispecie non compresi nella domanda dell'attore medesimo" ${ }^{70}$. Por outro lado, Vittorio Denti considera que a exceção visa a submeter ao objeto da cognição uma questão prejudicial a respeito da demanda, criando o dever de o juiz decidi-la antes da questão principal $^{71}$.

Não há dúvida que a dedução de um contradireito pela via da exceção substancial alarga o objeto de cognição do juiz no processo. A grande questão é saber se a amplitude da cognição significa a ampliação do mérito da causa. Entendendo-se este estritamente na visão do autor, como sendo a pretensão processual, dúvida não haverá no sentido de que o réu somente poderá ampliar o mérito deduzindo também ele uma pretensão. Porém, quando o réu deduz um contradireito ele também alega fatos jurídicos e deles pretende extrair consequências jurídicas. E, mesmo sem fazê-lo de forma explícita, o réu não deixa de pedir a declaração da existência do contradireito alegado. Sob esses aspectos a estrutura da exceção substancial (contradireito) não difere em nada da estrutura da pretensão processual. Fossem as coisas diferentes, a vontade do réu não teria o condão, como efetivamente tem, de vincular duplamente o juiz (positiva e negativamente) a respeito da alegação dos fatos que estão na base do contradireito ${ }^{72}$.

\footnotetext{
${ }^{69}$ DIDIER JÚNIOR, Fredie. Contradireitos, objeto litigioso do processo e improcedência. Revista de Processo. v.38, n.223. São Paulo: Revista dos Tribunais, 2013, p. 94. Também Cleanto Guimarães Siqueira entende que "as exceções substanciais deduzidas na defesa integram o mérito do processo, ampliando a res in judicio deducta" (SIQUEIRA, Cleanto Guimarães. A defesa no processo civil as exceções substanciais no processo de conhecimento. $3^{\text {a }}$ ed. São Paulo: Saraiva, 2008, p. 287).

${ }^{70}$ CARNELUTTI, Francesco. Diritto e processo. Napoli: Morano, 1958., p. 269.

${ }^{71}$ DENTI, Vittorio. L'eccezione nel processo cvile. Rivista trimestrale di diritto e procedeura civile. Anno XV. Milano: Dott. A. Giuffrè, 1961, p. 33.

${ }^{72}$ Em sentido semelhante, Aaraken de Assis, apesar de reconhecer que "a tese prevalecente é a de que o autor fixa, por sua iniciativa, o mérito, que recai unicamente sobre o pedido" adverte, em sentido contrário, que "o mérito não se cinge ao pedido, envolvendo também a causa de pedir (retro, 236), elementos da ação subordinados à iniciativa do autor", de modo que "se o juiz, ao acolher ou a rejeitar a exceção substancial, julga o mérito e, para esse efeito, encontra-se adstrito à iniciativa do réu em alegar semelhante exceção, pois do contrário não se conheceria da matéria, forçoso admitir que o mérito alargou-se além dos limites originais". E, desse modo, arremata: "passou a integrar-se, a partir da alegação do réu, questão que era estranha à propsota
} 
Revista Eletrônica de Direito Processual - REDP.

Rio de Janeiro. Ano 11. Volume 18. Número 2. Maio a Agosto de 2017

Periódico Quadrimestral da Pós-Graduação Stricto Sensu em Direito Processual da UERJ

Patrono: José Carlos Barbosa Moreira. ISSN 1982-7636. pp. 297-326

www.redp.uerj.br

Sob essa ótica, tem razão Didier quando afirma que "a decisão que não acolhe a prescrição resolve parte do mérito da causa - a parcela relacionada à afirmação do contradireito" e, consequentemente, é apta à coisa julgada ${ }^{73}$. Quando o juiz julga procedente o pedido do autor - considerando que não há prescrição - assim como quando não acolhe o pedido, por reconhecer a prescrição, há julgamento de mérito e, pois, formação da coisa julgada material $^{74}$. A sutil mudança operada no art. 487, II, do CPC, que substitui a expressão acolher por decidir sobre a prescrição também contribui para esse entendimento.

Na mesma linha, pode-se acrescentar o exemplo da exceção de usucapião. Quando o réu objetiva neutralizar o direito do autor alegando o seu direito à aquisição da propriedade pela usucapião ele sem dúvida amplia o mérito da causa. Note-se que, nesse caso, o juiz deverá decidir sobre a questão do mesmo modo como deverá decidir a questão principal. Tanto é verdade que haverá, aqui, uma ampliação do objeto litigioso, que o art. 13 da Lei 10.257/2001, estabelece que “a usucapião especial de imóvel urbano poderá ser invocada como matéria de defesa, valendo a sentença que a reconhecer como título para registro no cartório de registro de imóveis”. Isso quer dizer que a sentença que julgar improcedente o pedido do autor com fundamento no contradireito do réu fará coisa julgada, não somente a respeito do pedido do autor, mas também quanto ao contradireito do réu, ao ponto de valer como título para registro da propriedade no ofício imobiliário.

Contribui para essa tese o fato de o atual CPC ter adotado um regime de formação progressiva dos limites objetivos da coisa julgada. É que, de acordo com o art. 503, §1. ${ }^{\circ}$, do CPC, a formação da coisa julgada sobre as denominadas questões prejudiciais não depende

\footnotetext{
da inicial. Por óbvio, a eventual repercussão desses novos limites do mérito na coisa julgada é outro problema, a ser examinado oportunamnete, remarcando-se que, nos termos do art. 503, caput, a autoridade recai sobre as questões principais. O que não se pode negar, sem ofensa à realidade, é o alargamento não da cognitio do órgão judiciário, mas do próprio iudicium" (ASSIS, Araken de. Processo civil brasileiro. v. 1: parte geral: fundamentos e distribuição de conflitos. São Paulo: Revista dos Tribunais, 2015, pp. 947-948).

${ }^{73}$ DIDIER JÚNIOR, Fredie. Contradireitos, objeto litigioso do processo e improcedência. Revista de Processo. v.38, n.223. São Paulo: Revista dos Tribunais, 2013, p. 95.

${ }^{74}$ Afinal, "se não fosse assim, teríamos uma situação esdrúxula. Um direito (o contradireito) é afirmado em juízo, discutido em contraditório e decidido; se a afirmação for considerada procedente, há decisão de mérito e coisa julgada; se a afirmação for considerada improcedente, não há decisão de mérito e, pois, também não há coisa julgada. Teríamos uma coisa julgada secundum eventum litis - coisa julgada que surge de acordo com o resultado do processo -, em grave ofensa ao princípio da igualdade. Ou seja: decisão que não acolhe esse tipo de direito (o contradireito) jamais se submeteria à coisa julgada. Caso raro, possivelmente único, de direito que, mesmo não reconhecido judicialmente, poderia ser exercitado novamente, já que não haveria o óbice da coisa julgada" (DIDIER JÚNIOR, Fredie. Contradireitos, objeto litigioso do processo e improcedência. Revista de Processo. v.38, n.223. São Paulo: Revista dos Tribunais, 2013, p. 95).
} 
Revista Eletrônica de Direito Processual - REDP.

Rio de Janeiro. Ano 11. Volume 18. Número 2. Maio a Agosto de 2017

Periódico Quadrimestral da Pós-Graduação Stricto Sensu em Direito Processual da UERJ

Patrono: José Carlos Barbosa Moreira. ISSN 1982-7636. pp. 297-326

www.redp.uerj.br

da propositura de uma nova ação incidental de natureza declaratória. Note-se que Barbosa Moreira via, na ação declaratória incidental, um caso de cúmulo de ações que importava na dilatação do thema decidendum, tratando-se, pois, de um meio de ampliação do objeto litigioso $^{75}$. Ora, a possibilidade de formação da coisa julgada sobre questões prejudiciais, prevista no art. 503, $1^{\circ}$, do $\mathrm{CPC}$, nada mais é que o reconhecimento da formação progressiva do objeto litigioso, que poderá ser ampliado em face da afirmação de questões prejudiciais de mérito, as quais, uma vez decididas - e desde que seja respeitado o contraditório, não seja caso de revelia, o juiz tenha competência para julgá-la também como questão principal e não se trate de processo com restrições probatórias ou limitação da cognição - serão cobertas pela imutabilidade da coisa julgada.

Não há dúvida que a pretensão processual constitui o objeto do processo, na medida em que as atividades das partes e do juiz, desde o início do processo, tem nela sua razão de ser. É ela que dá vida ao processo e faz com que ele seja impulsionado à prestação da tutela jurisdicional. Tanto isso é verdade que o fato de o réu ter deduzido uma exceção substancial não impedirá que o processo seja extinto sem resolução do mérito quando, por exemplo, estiver ausente algum pressuposto processual como a incapacidade processual ou a irregularidade de representação da parte autora (art.76, §1. ${ }^{\circ}, \mathrm{I}, \mathrm{CPC}$ ). Caso o mesmo pressuposto processual faltasse ao réu, a consequência seria a decretação da revelia (art. 76, §1. ${ }^{\circ}$, II, CPC), na medida em que o processo não teria perdido o seu objeto. No entanto, como o processo é dinâmico, o objeto do processo (objeto litigioso) poderá ser alargado de modo a ser composto não somente pela pretensão processual deduzida pelo autor, como também por eventuais defesas substanciais deduzidos pelo réu. Isso, sem dúvida, impõe um conceito mais amplo de meritum causae, pois este passa a ser identificado também pelas

\footnotetext{
${ }^{75}$ Nesse sentido: “Com a propositura da ação declaratória incidente passa o processo a ter duplo objeto: ambas as questões - a subordinante e a subordinada - passam a ser questões principais, integrando o thema decidendum, que se dilata. Até então, o juiz teria sem dúvida de examinar a questão subordinante, mas apenas, repita-se como etapa lógica do seu itinerário mental. Agora, cumpre-lhe julgá-la. Desde a propositura da ação declaratória incidente, há processo cumulativo. O órgão judicial defronta-se com duas ações, a cada uma das quais corresponde um pedido perfeitamente individualizado. A sentença que esse pronunciar sobre ambas será objetivamente complexa: conterá, na verdade, pois julgamentos, o do pedido primitivo e o do pedido superveniente formulado (formulado pela mesma ou pela outra parte) de declaração da existência ou inexistência da relação jurídica subordinante. É profunda, como se vê, a transformação sofrida pela estrutura do processo quando se propõe ação declaratória incidente" (BARBOSA MOREIRA, José Carlos. Limites objetivos da coisa julgada no sistema do código de processo civil. Temas de direito processual: primeira série. São Paulo: Saraiva, 1977, p. 94).
} 
Revista Eletrônica de Direito Processual - REDP.

Rio de Janeiro. Ano 11. Volume 18. Número 2. Maio a Agosto de 2017

Periódico Quadrimestral da Pós-Graduação Stricto Sensu em Direito Processual da UERJ

Patrono: José Carlos Barbosa Moreira. ISSN 1982-7636. pp. 297-326

www.redp.uerj.br

exceções substanciais ${ }^{76}$. Nessa linha, ao considerar-se que as exceções substanciais compõem o mérito, torna-se ainda mais claro que elas vinculam o juiz nos mesmos termos que este se encontra vinculado pela pretensão processual. Também para composição das defesas de mérito vale-se do conceito de alegação de fato como ato imperativo de comunicação de um significado normativo que resulta positivamente regulado pelo ordenamento jurídico ${ }^{77}$. Cabe lembrar, com Cappelletti, que o ato imperativo se distingue dos atos meramente informativos, na medida em que nesses não há uma vinculação do juiz, o qual poderá valorar a informação quanto à sua correspondência com a efetiva situação de fato narrada ${ }^{78}$, o que faz com que o juiz fique duplamente vinculado, na medida em que deve "prendere in esame tutte e soltanto le allegazioni proposte delle parti",79. Afinal, somente numa perspectiva inquisitorial de processo é que as alegações deixam de ser um ato normativo vinculante, configurando-se, ao contrário, um mero ato informativo realizado pelas partes em juízo ${ }^{80}$.

O entendimento aqui adotado acerca das exceções substancias parece ser bem agasalhado pela ideia de uma formação progressiva do objeto litigioso, a qual, ao mesmo tempo em que procura lidar com a incompatibilidade da separação fato e direito com o

\footnotetext{
${ }^{76}$ Registre-se que o conceito de mérito aqui adotado, como sinônimo de objeto litigioso, não se confunde com o conceito de "lide", que, para o Código de Processo Civil de 1973, seria sinônimo de mérito (conforme item 6 da exposição de motivos do Código). Conforme Ovídio A. Baptista da Silva, as proposições doutrinárias segundo as quais mérito é igual a lide prendem-se a duas premissas lógicas: ": (a) a decisão de mérito resumese no ato de julgar, por isso se diz que "julgar a lide" e "julgar o mérito" são expressões sinônimas; (b) somente há julgamento verdadeiro, portanto, decisão de mérito, quando o juiz profere decisão sobre o pedido do autor, "para julgá-lo procedente ou improcedente", o que significa que qualquer outra manifestação do julgador que não traduza um julgamento definitivo não seria de mérito" (SILVA, Ovídio Araújo Baptista da. Conteúdo da sentença e mérito da causa. Sentença e coisa julgada: ensaios e pareceres. 4. ed. Rio de Janeiro: Forense, 2003, p. 306). Para aprofundar a crítica à equiparação entre mérito e lide, consultar também DINAMARCO, Candio Rangel. O conceito de mérito em processo civil. Revista de processo. v. 34. São Paulo: Revista dos Tribunais, 1984.

${ }^{77}$ CAPPELLETTI, Mauro. La testimonianza della parte nel sistema dell'oralità: contributo alla teoria della utilizzazione probatória del sapere delle parti nel processo civile. Parte prima. Milano: Dott. A. Giuffrè Ditore, 1962 , p. 329.

78 CAPPELLETTI, Mauro. La oralidad y las pruebas en el proceso civil. Traducción de Santiago Sentís Melendo. Buenos Aires: Ediciones Juridicas Europa-America, 1972, p. 121.

${ }^{79}$ CAPPELLETTI, Mauro. La testiomianza della parte nel sistema dell'oralità: contributo alla teoria della utilizzazione probatoria del sapere delle parti nel processo civile. Parte prima. Milano: Dott. A. Giuffrè Editore, 1962, p. 323.

${ }^{80}$ CAPPELLETTI, Mauro. La testiomianza della parte nel sistema dell'oralità: contributo alla teoria della utilizzazione probatoria del sapere delle parti nel processo civile. Parte prima. Milano: Dott. A. Giuffrè Editore, 1962, p. 323.
} 
Revista Eletrônica de Direito Processual - REDP.

Rio de Janeiro. Ano 11. Volume 18. Número 2. Maio a Agosto de 2017

Periódico Quadrimestral da Pós-Graduação Stricto Sensu em Direito Processual da UERJ

Patrono: José Carlos Barbosa Moreira. ISSN 1982-7636. pp. 297-326

www.redp.uerj.br

caráter dinâmico do processo e unitário do juízo decisório ${ }^{81}$, reforça os vínculos dialógicos do modelo democrático de processo. Nesse sentido, pode-se mencionar a tese defendida por Giancarlo Giannozzi, segundo o qual a demanda é formada por estados sucessivos dentro de um limite que tem seu marco final no momento em que o juiz esteja pronto para passar à fase de instrução e decisão da causa ${ }^{82}$. No fundo do seu pensamento está o caráter dinâmico do processo e impossibilidade de traçar um quadro jurídico para os fatos deduzidos pelo autor desde o início da causa. Para o jurista italiano a prospettazion giuridica dos fatos constituiria o elemento variável e elástico da causa de pedir ${ }^{83}$.

A complexidade do material fático-jurídico que perpassa a formação do objeto litigioso no iter procedimental impõe que se fale não mais de uma formação estática do objeto litigioso, mas, sim, que se admita que ele se forma de maneira dinâmica e progressiva. Permite-se, com isso, abandonar o esquema distributivo do papel das partes e do juiz segundo o qual àqueles cabem os fatos e a este o direito. Contribuem, para essa mudança (i) o modelo cooperativo de processo (art. $6^{\circ}$. CPC), segundo o qual cabe ao juiz convidar as partes a beneficiarem todos os articulados apresentados, convocar as partes para esclarecimento dos fatos e para delimitação dos termos do litígio ${ }^{84}$, e, (ii) o perfil democrático do processo, que impõe a revalorização do princípio do contraditório como fator legitimador do processo, impõe que a alteração da qualificação jurídica dos fatos dependa que seja possibilitado às partes o seu debate em contraditório ${ }^{85}$. Nessa senda, o brocardo iura novit curia, comumente utilizado para permitir que o juiz, de ofício, possa se imiscuir

\footnotetext{
81 Conforme Ovídio A. Baptista da Silva, “o Direito, como ciência da compreensão, existe no 'fato', hermeneuticamente interpretado" (BAPTISTA DA SILVA, Ovídio A. Processo e ideologia: o paradigma racionalista. Rio de Janeiro: Forense, 2004, p. 36). Para Castanheira Neves, talvez o jurista que com maior precisão tenha conseguido desvencilhar a metodologia jurídica do esquema normativista e apontar a inexorabilidade entre fato e direito, “"o puro fato' e 'puro direito' não se encontram nunca na vida jurídica: o facto não tem existência senão a partir do momento em que se torna matéria de aplicação do direito, o direito não tem interesse senão no momento em que trata de aplicar o facto". Consequentemente, "quando o jurista pensa o facto, pensa-o como matéria do direito, quando pensa o direito, pensa-o como forma destinada ao facto" (CASTANHEIRA NEVES, António. Questão-de-facto - Questão-de-direito ou o Problema metodológico da juridicidade (ensaio de uma reposição crítica). Coimbra: Livraria Almedina, 1967, pp. 5556).

82 GIANNOZZI, Giancarlo. La modificazione della domanda nel processo civile. Milano: Dott. A. Giuffrè, 1958 , p. 22.

83 GIANNOZZI, Giancarlo. La modificazione della domanda nel processo civile. Milano: Dott. A. Giuffrè, 1958, p. 27.

${ }^{84}$ MACHADO, António Montalvão. O dispositivo e os poderes do tribunal à luz do novo código de processo civil. $2^{\text {a }}$ ed. Coimbra: Almedina, 2001, p. 293.

${ }^{85}$ MOTULSKY, Henri. Écrits: études et notes de procédure civile. Paris: Dalloz, 1973, p. 298.
} 
Revista Eletrônica de Direito Processual - REDP.

Rio de Janeiro. Ano 11. Volume 18. Número 2. Maio a Agosto de 2017

Periódico Quadrimestral da Pós-Graduação Stricto Sensu em Direito Processual da UERJ

Patrono: José Carlos Barbosa Moreira. ISSN 1982-7636. pp. 297-326

www.redp.uerj.br

em questões jurídicas não debatidas pelas partes, deve ser repensado. O iura novit curia não implica uma expectativa fiel das partes sobre a capacidade de o juiz encontrar corretamente e solitariamente a melhor solução jurídica para os fatos da causa ${ }^{86}$. Na verdade, se o processo se desenvolve no diálogo entre as partes e o juiz - eis aqui o cerne da ideia de colaboração no processo civil - deve ser afastada qualquer forma de solipsismo processual do magistrado mesmo naquilo que lhe é dado conhecer de ofício ${ }^{87}$.

Sob essa perspectiva torna-se possível dizer que o juiz e as partes deverão colaborar na determinação do thema decidendum, vale dizer, do objeto litigioso, do mérito da causa ${ }^{88}$. Para tanto, deve-se superar a visão meramente estática do objeto litigioso, de modo que as circunstâncias de fato levantadas pelo autor com a demanda estejam abertas à modificação e à integração a ser desenvolvida na fase preparatória da causa a partir de uma atividade conjunta entre o juiz e as partes. Essa intervenção sobre as hipóteses fáticas trazidas no início do processo "significa mantenere 'aperta' la strada verso un perfezionamento (possibile) del materiale sul quale il giudice dovrà compiere la costruzione del caso da porre alla base della decisione $" 89$.

Tal proposta visa a otimizar a atividade jurisdicional, em atenção aos princípios da efetividade da tutela jurisdicional e da razoável duração do processo. A atividade de modificação progressiva do objeto litigioso visa, desse modo, a favorecer uma individualização qualitativamente correta do thema decidendum ${ }^{90}$. Note-se que, com isso, tem-se uma potencialização do diálogo judicial mormente em relação àquele que é o ponto nevrálgico da limitação dos poderes das partes e do juiz no processo: a modelagem da espessura jurídica dos fatos alegados pelas partes. Trata-se, pois, de uma forma de otimizar

\footnotetext{
${ }^{86}$ BUONCRISTIANI, Dino. Il nuovo art. 101, comma $2^{\circ}$, C.P.C. sul contraddittorio e sui rapporti tra parti e giudice. Rivista di diritto processuale. Anno LXV (Seconda Serie) - N. 2. Marzo- Aprile 2010. Padova: CEDAM, 2010, p. 408.

${ }^{87}$ GRADI, Marco. Il principio del contraddittorio e la nullità dela sentenza dela "terza via". Rivista di diritto processuale. Anno LXV (Seconda Serie) N. 4. Luglio-Agosto 2010. Padova: CEDAM, 2010, p. 826.

${ }^{88}$ COSTANTINO, Giorgio. Questioni processuali tra poteri del giudice e facoltà delle parti. Rivista di diritto processauel. Anno LXV (Seconda Serie) - N. 5. Settembre-Ottobre 2010. Padova: CEDAM, 2010, p. 1012.

${ }^{89}$ GAMBA, Cinzia. Domande senza risposta: studi sulla modificazione della domanda nel proceso civile. Milano: CEDAM, 2008, p. 174

${ }^{90}$ GAMBA, Cinzia. Domande senza risposta: studi sulla modificazione della domanda nel proceso civile. Milano: CEDAM, 2008, p. 176.
} 
Revista Eletrônica de Direito Processual - REDP.

Rio de Janeiro. Ano 11. Volume 18. Número 2. Maio a Agosto de 2017

Periódico Quadrimestral da Pós-Graduação Stricto Sensu em Direito Processual da UERJ

Patrono: José Carlos Barbosa Moreira. ISSN 1982-7636. pp. 297-326

www.redp.uerj.br

a formação do objeto litigioso, bem como da sucessiva fase instrutória e decisória sob um plano de equilíbrio dos poderes das partes e do juiz no processo ${ }^{91}$.

Isso, no entanto, não significa que retirar das partes a disponibilidade quanto à limitação do objeto litigioso. $\mathrm{O}$ debate, portanto, deve ficar restrito à delimitação normativa do objeto litigioso, notadamente no que diz respeito as possíveis teses jurídicas sobre ele desenvolvidas. A autonomia privada, no processo civil, impõe que caiba às partes, e tão somente a elas, limitar o âmbito do exercício da função jurisdicional. Do contrário, como afirma Montesano, entender que o juiz possa decidir fora dos limites da causa de pedir - e também das exceções substanciais deduzidas pelo réu - equivaleria a dizer que poderia promover uma nova causa que ele mesmo iria julgar ${ }^{92}$.

\section{Considerações finais}

O estudo do objeto do processo - objeto litigioso ou mérito da causa - é essencial para a resolução do problema da divisão de trabalho entre o juiz e as partes $^{93}$ e, mais precisamente, para estabelecer os limites de atuação de ofício do juiz no processo civil. Por certo que não se trata de uma tarefa simples, até porque existem muitas controvérsias acerca

\footnotetext{
${ }^{91}$ Conforme Cinzia Gama, "in vari ordinamenti processuali moderni emerge la tendenza a porre in direta correlazione l'attività di precisazione e modificazione della domanda e, più in generale, della allegazione e delle difese con l'esercizio dei poteri di direzione materiale da parte del giudice, il quale e con la loro collaborazione, definisce quali siano le questioni realmente controverse, destinate a formare oggetto di istruzione e sucessiva decisione" (GAMBA, Cinzia. Domande senza risposta: studi sulla modificazione della domanda nel proceso civile. Milano: CEDAM, 2008, p. 197).

${ }^{92}$ Nessa perspectiva, Montesan entende que permitir o juiz pudesse decidir fora dos limites da causa de pedir equivaleria a dizer que o juiz "può promuovere uma nuova causa (...) che elgi stesso deve decidere" (MONTESANO, Luigi. "Pubblico" e "privato" in norme del codice civile sulla tutela giurisdizionale dei diritti. Rivista di diritto processuale. $\mathrm{n}$. 4. Padova: CEDAM, 1992, pp. 1015-1016). Atrelado tanto a demanda quanto a causa de pedir à vontade das partes, refere Dino Buonscritiani: "nel processo civile la tutela giudiziaria è rimessa alla volontà del postulante; è l'attore a proporre la domanda; nel momento in cui propone la domanda, deve effettuare la scelta del giudice a cui rivolgersi e della controparte da convenire in giudizio; se questa scelta dipende dall'allegazione della causa petendi, è il postulante a dover esporre in fatto le ragioni della domanda; tale allegazione, anche se non necessaria per individuare il diritto controverso, cioè la pretesa, è necessaria per lo svolgimento del giudizio o meglio per la richiesta di tutela; dato che la richiesta di tutela è rimessa alla volontà di parte, anche l'allegazione della causa petendi, in quanto necessaria per tale richiesta di tutela, è rimessa al potere esclusivo della parte" (BUONCRISTIANI, Dino. L'allegazione dei fatti nel processo civile: profili sistematici. Torino: G. Giappichelli Editore, 2001, p. 72).

${ }_{93}$ A expressão disseminou-se no direito brasileiro com Barbosa Moreira. A respeito, ver BARBOSA MOREIRA, José Carlos. O problema da divisão de trabalho entre juiz e partes: aspectos terminológicos. In: Temas de direito processual. $4^{\text {a }}$ série. São Paulo: Saraiva, 1989. Trata-se, nas palavras de Araken de Assis, do "problema capital do processo civil contemporâneo". Seu estudo é de suma importância uma vez que "é na ênfase maior ou menor na atividade das partes e na atividade do juiz que se expressa as linhas ideológicas do ordenamento processual" (ASSIS, Araken de. Processo civil brasileiro. Volume II: parte geral: institutos fundamentais: Tomo 1. São Paulo: Revista dos Tribunais, 2015. p. 894).
} 
do próprio conteúdo do mérito da causa. Porém, na medida em que o processo civil deve ser estudado numa perspectiva garantista e, consequentemente, a jurisdição, passa a ser pensada como "un servizio che lo Stato deve asicurare per soddisfare la domanda di giustizia dei privati" ${ }^{94}$, torna-se indispensável que a doutrina processual lance o seu olhar para referido problema. De nada adianta pensarmos o processo civil sob a perspectiva do Estado Democrático de Direito se ele não for pensado a partir da sua "moldura garantísticoconstitucional” ${ }^{95}$. Por conseguinte, sob essa ótica, em que cabe ao processo garantir que o exercício da função jurisdicional - a qual é serviço público a serviço dos cidadãos - ocorra sem árbitro ou excessos ${ }^{96}$, o estabelecimento de limites à atuação de ofício do órgão jurisdicional torna-se um dos mais importantes temas da processualística civil.

Desse modo, o presente ensaio, longe de abarcar todas as perspectivas acerca do tema, procurou destacar as exceções substanciais como um dos componentes do objeto do processo e, consequentemente, erigi-las, pela via da (boa) dogmática processual, à condição de elemento crucial para a limitação da atuação de ofício do juiz no processo civil, ao lado do pedido e da causa de pedir. Nessa linha, mostra-se, ainda, possível ressaltar que a delimitação do objeto do processo ocorre de modo dinâmico na sistemática processual, seja pelo alargamento operado pelas exceções substanciais, seja pela inseparabilidade entre fato e direito, o que pressupõe que a delimitação/interpretação do o objeto litigioso pressuponha uma necessária (e legitimadora) participação das partes no iter procedimental.

\section{REFERÊNCIAS BIBLIOGRÁFICAS:}

ALSINA, Hugo. Defensas y excepciones. Buenos Aires: Ediciones juridicas europa-america - EJEA, 1958.

ASENJO, Jiménez. Teoría del objeto procesal. Revista de derecho privado. XXXIV, n. 398, 1950.

\footnotetext{
${ }^{94}$ CIRPIANI, Franco. Il processo civile nello Stato democrático. In: Il processo civile nello Stato democrático. Saggi. Collana biblioteca di diritto processuale. Napoli: Edizioni Scientifiche Italiane, 2006, p. 18.

${ }^{95}$ DELFINO, Lúcio. Como construir uma interpretação garantista do processo jurisdicional? Revista brasileira de direito processual-RBDpro. Ano. 25, n. 98. Abr./jun. 2017. Belo Horizonte: Editora Fórum, 2017, p. 217.

96 COSTA, Eduardo José da Fonseca. O processo como instituição de garantia. Disponível em <http://www.conjur.com.br/2016-nov-16/eduardo-jose-costa-processo-instituicao-garantia>. Acesso em $18 \mathrm{de}$ novembro de 2016.
} 
ASSIS, Araken de. Processo civil brasileiro. v. 1: parte geral: fundamentos e distribuição de conflitos. São Paulo: Revista dos Tribunais, 2015.

Processo civil brasileiro. Volume II: parte geral: institutos fundamentais: Tomo 1. São Paulo: Revista dos Tribunais, 2015.

Cumulação de ações. 4. ed. São Paulo: Rev. dos Tribunais, 2002.

BARBOSA MOREIRA, José Carlos. O problema da divisão de trabalho entre juiz e partes: aspectos terminológicos. In: Temas de direito processual. $4^{\text {a }}$ série. São Paulo: Saraiva, 1989. . Limites objetivos da coisa julgada no sistema do código de processo civil. Temas de direito processual: primeira série. São Paulo: Saraiva, 1977.

BERZOSA FRANCOS, Maria Victoria. Demanda, 'causa petendi' y objeto del proceso. Cordoba: El Almendro, 1984.

BÜLOW, Oskar. La teoria de las excepciones procesales y los presupuestos procesales. Buenos Aires: EJEA, 1964.

BUONCRISTIANI, Dino. Il nuovo art. 101, comma $2^{\circ}$, C.P.C. sul contraddittorio e sui rapporti tra parti e giudice. Rivista di diritto processuale. Anno LXV (Seconda Serie) - N. 2. Marzo- Aprile 2010. Padova: CEDAM, 2010.

L'allegazione dei fatti nel processo civile: profili sistematici. Torino: G. Giappichelli Editore, 2001.

CABRAL, Antônio do Passo. Coisa julgada e preclusões dinâmicas: entre continuidade, mudança e transição de posições processuais estáveis. Salvador: Editora JusPODIVM, 2013. CAPPELLETTI, Mauro. La oralidad y las pruebas en el proceso civil. Traducción de Santiago Sentís Melendo. Buenos Aires: Ediciones Juridicas Europa-America, 1972.

La testimonianza della parte nel sistema dell'oralità: contributo alla teoria della utilizzazione probatória del sapere delle parti nel processo civile. Parte prima. Milano: Dott. A. Giuffrè Ditore, 1962.

L'eccezione come controdiritto del convenuto. Rivista di diritto processuale. v. XVI. Padova: CEDAM, 1961.

CARNELUTTI, Francesco. Diritto e processo. Napoli: Morano, 1958.

CASTANHEIRA NEVES, António. Questão-de-facto - Questão-de-direito ou o Problema metodológico da juridicidade (ensaio de uma reposição crítica). Coimbra: Livraria Almedina, 1967. 
CATENA. Víctor Moreno. Derecho Procesal civil. Madrid: Editorial Colex, 1997.

CHIOVENDA, Giuseppe. Sulla "eccezione". Saggi di diritto processuale civile. Volume primo. Roma: Società editrice Foro Italiano, 1930.

CIRPIANI, Franco. Il processo civile nello Stato democrático. In: Il processo civile nello Stato democrático. Saggi. Collana biblioteca di diritto processuale. Napoli: Edizioni Scientifiche Italiane, 2006.

CORRÊA, Fábio Peixinho Gomes. O objeto litigioso no processo civil. São Paulo: Quartier Latin, 2009.

COSTA, Eduardo José da Fonseca. O processo como instituição de garantia. Disponível em <http://www.conjur.com.br/2016-nov-16/eduardo-jose-costa-processo-instituicaogarantia>. Acesso em 18 de novembro de 2016.

COSTA, Emillio. Profilo storico del processo civile romano. Roma: Athenaeum, 1918.

COSTANTINO, Giorgio. Questioni processuali tra poteri del giudice e facoltà delle parti. Rivista di diritto processauel. Anno LXV (Seconda Serie) - N. 5. Settembre-Ottobre 2010. Padova: CEDAM, 2010.

COUTURE, J. Eduardo. Fundamentos del derecho procesal civil. Segunda edición ampliada y actualizada. Buenos Aires: Editorial Depalma, 1951.

DE STEFANO, Giuseppe. L'oggetto del processo in un libro recente di Walter J. Habscheid. Scritti giuridici in memoria di Piero Calamandrei. Volume Terzo. Padova: CEDAM, 1958. Per una teoria dell'oggetto del processo. Scritti giuridici in memoria di Piero Calamandrei. Volume Terzo. Padova: Casa Editrice Dott. Antonio Milani, 1958.

DELFINO, Lúcio. Como construir uma interpretação garantista do processo jurisdicional? Revista brasileira de direito processual - RBDpro. Ano. 25, n. 98. Abr./jun. 2017. Belo Horizonte: Editora Fórum, 2017.

DENTI, Vittorio. L'eccezione nel processo cvile. Rivista trimestrale di diritto e procedeura civile. Anno XV. Milano: Dott. A. Giuffrè, 1961.

DIDIER JÚNIOR, Fredie. Contradireitos, objeto litigioso do processo e improcedência. Revista de Processo. v.38, n.223. São Paulo: Revista dos Tribunais, 2013.

DINAMARCO, Candido Rangel. Instituições de direito processual civil. $6^{\mathrm{a}}$ ed. São Paulo: Malheiros, 1999. 
. O conceito de mérito em processo civil. Revista de processo. v. 34. São Paulo:

Revista dos Tribunais, 1984.

DOMÍNGUEZ, Valentín Cortés. SENDRA, Vicente Gomeno. CATENA. Víctor Moreno. Derecho Procesal civil. Madrid: Editorial Colex, 1997.

GIANNOZZI, Giancarlo. La modificazione della domanda nel processo civile. Milano: Dott.

A. Giuffrè, 1958.

GIORDANI, Mário Curtis. Processo civil romano: noções elementares. São Paulo: Idéias e Letras, 2010.

GRADI, Marco. Il principio del contraddittorio e la nullità dela sentenza dela "terza via". Rivista di diritto processuale. Anno LXV (Seconda Serie) N. 4. Luglio-Agosto 2010. Padova: CEDAM, 2010.

GUASP, Jaime. Juez y hechos en el proceso civil: una crítica del derecho de disposición de las partes sobre el material de hecho del proceso. Barcelo: Bosch, 1943.

GUASP. Jaime. La pretensión procesal. $2^{\mathrm{a}}$ ed. Prólogo de Manuel Alonso Olea. Madrid: Editorial Civitas, S.A., 1985.

HABSCHEID, Walter. L'action en justice. In: Droit judiciaire privé suiss. Genève: Ed. Liberairée de L’Université Georgetcie S.A, 1981.

L’oggetto del proceso nel diritto processuale civile tedesco. Rivista di diritto processuale. XXXV, II serie. Padova: CEDAM, 1980.

LENT, Friedrich. Contributo alla dottrina dell'oggetto del processo. Rivista JUS. Milano, 1953.

LOPES DA COSTA, Alfredo de Araújo. Direito processual civil brasileiro (Código de 1939). V. 2. Rio de Janeiro: José Konfino, 1946.

MACHADO, António Montalvão. O dispositivo e os poderes do tribunal à luz do novo código de processo civil. $2^{\mathrm{a}}$ ed. Coimbra: Almedina, 2001.

MILONE, Filippo. La exceptio doli (generalis): studio di diritto romano. Napoli: Riccardo Marghieri di Gius, 1882.

MONTEIRO, André Luís. O regime das exceções no direito processual civil brasileiro: de mérito e processual, direta e indireta, dilatória e peremptória, exceção e objeção. Revista de processo. Ano 38. Volume 216. São Paulo: Revista dos Tribunais, 2013. 
MONTESANO, Luigi. "Pubblico" e "privato" in norme del codice civile sulla tutela giurisdizionale dei diritti. Rivista di diritto processuale. n. 4. Padova: CEDAM, 1992.

MORTARA, Lodovido. Manuale della procedura civile. Volume primo. Torino: Unione Tipografico-Editrice Torinense, 1910.

MOTULSKY, Henri. Écrits: études et notes de procédure civile. Paris: Dalloz, 1973.

ORTOLAN, M. Compendio del derecho romano. Buenos Aires: Atalaya, 1947.

PENALVA, Ernesto Pedraz. El objeto del proceso civil. Madrid: Edit. Consejo general del poder judicial, 1996.

PICÓ I JUNOY, Joan. La modificación de la demanda en el processo civil: reflexiones sobre la prohibición de mutatio libelli. Valencia: Tirant lo blanch, 2006.

PONTES DE MIRANDA, Francisco Cavalcanti. Tratado de direito privado. Tomo VI. Rio de Janeiro: Borsoi, 1955.

RAATZ, Igor. Autonomia privada e processo civil: negócios jurídicos processuais, flexibilização procedimental e o direito à participação na construção do caso concreto. Salvador: Juspodivm, 2016.

RAMOS, Manuel Ortells. Derecho procesal civil. Navarra: Aranzadi Editorial, 2000.

REIS, José Alberto dos. Código de processo civil anotado. Voluma II. Artigos 487 a $549.4^{\mathrm{a}}$ ed. Coimbra: Coimbra, 1985.

RIBEIRO, Darci Guimarães. Objeto do processo e objeto o debate: dicotomia essencial para uma adequada compreensão do novo CPC. Desvendando o novo CPC. Darci Guimarães Ribeiro, Marco Félix Jobim (organizadores). Porto Alegre: Livraria do Advogado, 2015.

SANCHES, Sydnei. Objeto do processo e objeto litigioso do processo. AJURIS. n. 16. Porto Alegre: AJURIS, 1979.

SANTOS, Andrés de La Oliva. GIMÉNEZ, Ignacio Díez-Picazo. Derecho procesal civil: el proceso de declaración. Conforme a la ley 1/2000, de 7 de enero de enjuciamiento civil. Madrid: Editorial centro de estudios ramón areces S.A, 2000.

SCHWAB, Karl Heinz. Introdução ao direito processual civil alemão. v. 3. Revista de Processo. São Paulo: Revista dos Tribunais, 1976.

El objeto litigioso en el proceso civil. Traducción del alemán por Tomas A. Banzhaf. Buenos Aires: E.J.E.A., 1968. 
. La teoria dell'oggetto del processo nell'attuale dottrina tedesca. Studi in onore di Antonio Segni. v. IV. Milano: Casa editrice dott. a. giuffrè, 1967.

SCIALOJA, Vittorio. Procedura civile romana; esercizio e difesa dei diritti. Roma: Anonima Romana, 1936.

SERPA LOPES, Miguel Maria. Exceções substanciais: exceção de contrato não cumprido (exceptio non adimpleti contractus). Rio de Janeiro: Freitas Bastos, 1959.

SICA, Heitor Vitor Mendonça. O direito de defesa no processo civil brasileiro: um estudo sobre a posição do réu. São Paulo: Atlas, 2011.

SILVA, Ovídio A. Baptista da. Curso de processo civil, volume 1: processo de conhecimento. $7^{\mathrm{a}}$ ed., Rio de Janeiro: Forense, 2005.

Processo e ideologia: o paradigma racionalista. Rio de Janeiro: Forense, 2004.

SIQUEIRA, Cleanto Guimarães. A defesa no processo civil as exceções substanciais no processo de conhecimento. $3^{\mathrm{a}}$ ed. São Paulo: Saraiva, 2008.

TARZIA, Giuseppe. Problemi del processo civile di cognizione. Padova: CEDAM - Casa Editrice Dott. Antonio Milani, 1989.

VILLEY, Michel. Direito romano. Tradução de Fernando Couto. Porto: Editora Resjuridica, 1991. 